

\begin{tabular}{c|c|c|c}
1 & 2 & 3 & 4 \\
\hline 5 & & 6 & \\
\hline & 7 & & 8 \\
\hline 9 & & 10 & \\
\hline 11 & 12 & 13 & 14
\end{tabular}

1. Asbestos ore

2. Lead ore-Balmat Mine, N. Y.

3. Chromite-chromium ore, Wash

4. Zinc ore-Friedensville, $\mathrm{Pa}$.

5. Banded iron formation, Palmer. Michigan

6. Ribbon asbestos ore, Quebec, Canada

7. Manganese ore, banded

rhodochrosite
8. Aluminum ore, bauxite, Georgia

9. Native copper ore, Keweenawan Peninsula, Mich:

10. Porphyry molybdenum ore, Colo.

11. Zinc ore, Edwards, N. Y

12. Manganese nodules, ocean floor

13. Botryoidal fluorite ore, Poncha Springs, Colo.

14. Tungsten ore, North Carolina 


\section{The Nature and Use of Copper Reserve and Resource Data}

By DENNIS P. COX, NANCY A. WRIGHT, and GEORGE J. COAKLEY

GEOLOGY AND RESOURGES OF GOPPER DEPOSITS

GEOLOGICAL SURVEY PROFESIONAL PAPER 907-F

A discussion of the use and limitations

of copper resource data for

production estimates, trends, and forecasts

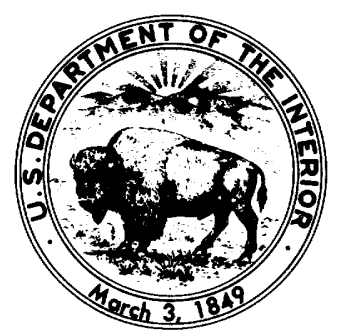


UNITED STATES DEPARTMENT OF THE INTERIOR

JAMES G. WATT, Secretary

GEOLOGICAL SURVEY

Dallas L. Peck, Director

Library of Congress Cataloging in Publication Data

Cox, Dennis P.

The nature and use of copper reserve and resource data.

(Geology and resources of copper deposits)

(Geological Survey professional paper ; 907-F)

Bibliography: p.

Supt. of Does. no.: I 19.16:907-F

1. Copper cores-United States. I. Wright, Nancy A., joint author. III. Title. IV. Series. V. Series: United States. Geological Suvey. Professional paper ; 907-F. TN443.A5C69 $553.4^{\prime} 3^{\prime} 0973 \quad 80-607780$

For sale by the Superintendent of Documents, U.S. Government Printing Office Washington, D.C. 20402 


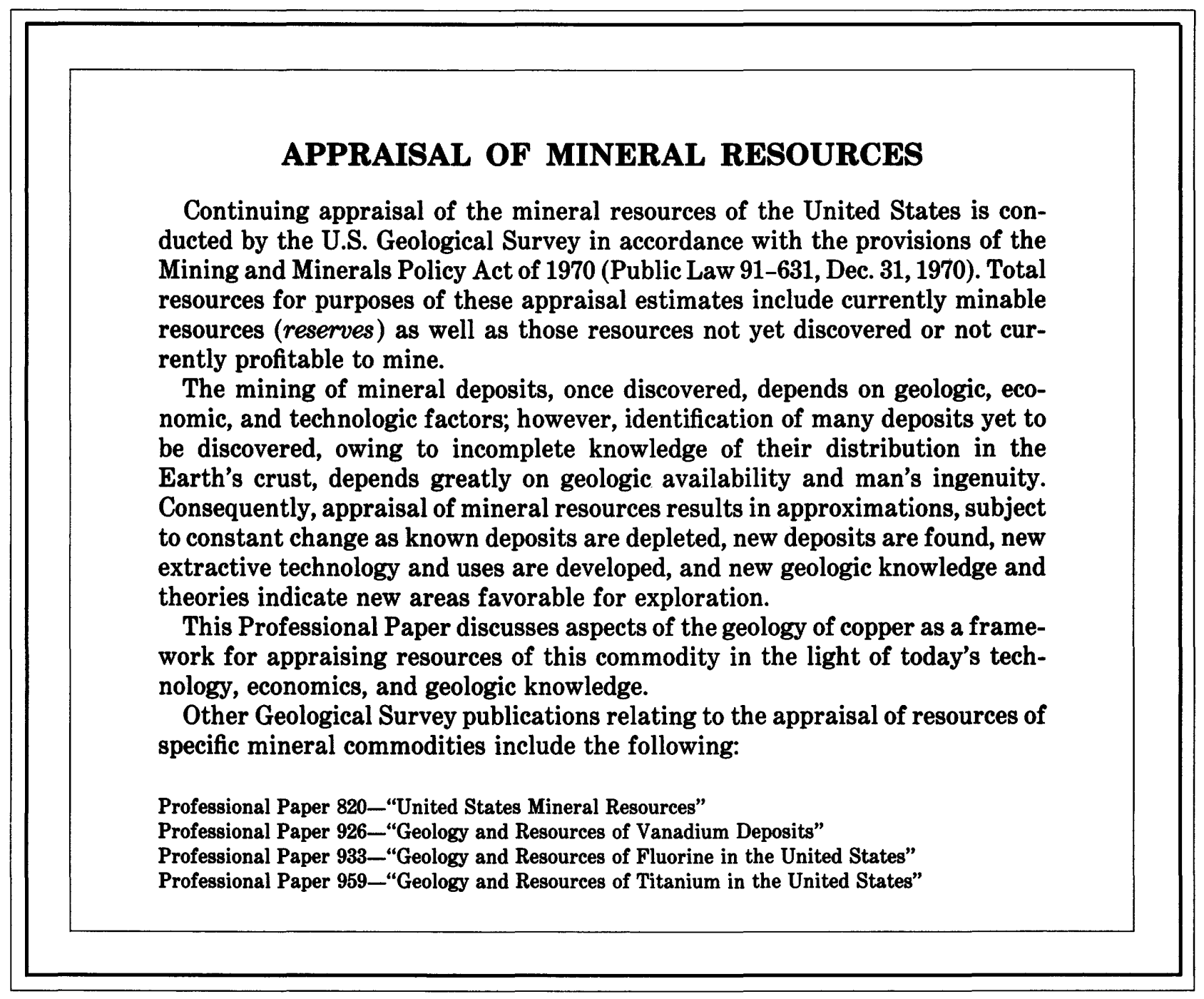


. 


\section{CONTENTS}

Abstract
Introduction
Acknowledgments
Definitions of terms
Sources of data and methods of analysis
Reserve data
Total ore and contained copper
Resource data
Production data
Anticipated copper production
Requirements for new sources
Conclusions
References cited

\section{ILLUSTRATIONS}

FIGURE 1. Graph showing U.S. reserve estimates and annual production 1925-1977

2. Plot showing tonnage and grade of U.S. copper deposits

3. Graph showing declining yield of U.S. copper mines, 1936-1976

4. Diagram showing classification of U.S. copper resources and reserves

5. Plot showing relation of annual production capacity to total copper in ore for 34 deposits

6. Diagram comparing copper demand with U.S. production capacity projections 1976-2030

7. Graph showing cumulative reserves and resources at various grades in the United States, Chile, Peru, Zambia, and Zaire, as of 1977

8. Bar chart showing tonnage of copper in reserves and number of deposits brought into production that are potentially producible, graph showing cumulative copper in developed ore reserves, cumulative consumption, and cumulative mine production.

\section{TABLES}

TABLE 1. Published reserves and resources of copper deposits in the United States

2. The sensitivity of U.S. copper reserves to economic conditions, in 1975

3. Total copper contained in typical deposits

4. Copper resources of the United States as of $\mathbf{1 9 7 8}$ 


\title{
THE NATURE AND USE OF COPPER RESERVE AND RESOURCE DATA
}

\author{
By Dennis P. Cox, Nancy A. Wright, and George J. Coakley ${ }^{1}$
}

\section{ABSTRACT}

Copper reserve, resource, and production data can be combined to produce disaggregated resource estimates and trends and, when combined with demand forecasts, can be used to predict future exploration and development requirements.

Reserve estimates are subject to uncertainties due mainly to incomplete exploration and rapidly changing economic conditions. United States' reserve estimates in the past have been low mainly because knowledge of the magnitude of very large porphyry-copper deposits has been incomplete. Present estimates are considerably more reliable because mining firms tend to drill out deposits fully before mining and to release their reserve estimates to the public.

The sum of reserves and past production yields an estimate of the total ore, total metal contained in ore, and average grade of ore originally in each of the deposits known in the United States. For most deposits, estimates of total copper in ore are low relative to the total copper in mineralized rock, and many estimates are strongly affected by the economic behavior of mining firms. A better estimate of the real distribution of copper contained in deposits can be obtained by combining past production data with resource estimates.

Copper resource data are disaggregated into categories that include resources in undeveloped deposits similar to those mined in the past, resources in mines closed because of unfavorable economic conditions, resources in deep deposits requiring high-cost mining methods, and resources in deposits located in areas where environmental restrictions have contributed to delays in development. The largest resource is located in the five largest porphyry deposits. These deposits are now being mined but the resources are not included in the present mining plan. Resources in this last category will not contribute to supply until some future time when ores presently being mined are depleted.

A high correlation exists between total copper contained in deposits and annual production from deposits. This correlation can be used to predict roughly the potential production from undeveloped deposits. Large deposits annually produce relatively less metal per ton of copper contained than do medium and small deposits.

Dividing reserves by annual production gives a depletion date for each copper mine. The sum of annual production capacity of all mines not yet depleted at any year of interest gives the minimum production capacity for that year. A graph of minimum production capacity by year combined with curves representing potential capacity from undeveloped identified resources can be compared with various demand scenarios to yield a measure of copper requirements from new sources.

Since 1950 reserves have been developed in the United States at a rate of about 1 million tons of copper per year. Since 1960 the number of deposits developed per 10-year period has greatly increased without a commensurate increase in tonnage of copper. This is in part due to the fact that recent exploration successes have been increasingly represented by smaller and (or) lower grade deposits containing less metal.

\section{INTRODUCTION}

The objectives of this report are to describe the nature and limitations of the data on copper resources, to

'U.S. Bureau of Mines, 2401 E Street N.W., Columbia Plara, Room 1102, Washington, D.C. 20241. show how the data can be used to produce resource estimates, and to illustrate some of the ways in which trends and forecasts can be derived from the data.

Throughout this report, the reader is shown repeatedly that the data on copper resources contain inherent limitations on accuracy and that projections of future rates of resource development made from the data are affected by economic and technological factors that are themselves difficult to project. Although we acknowledge the limitations of such resource analysis, we feel that the analysis does illustrate methods of data treatment that may become useful parts of more complex models of copper supply.

Many comprehensive reviews of U.S. copper reserves, technology, and supply have been made by specialists in the U.S. Bureau of Mines. Prominent among these are McMahon (1965), Everett and Bennett (1967), Bennett and others (1973), and Schroeder (1977). In contrast to these reports, our study focuses on some alternatives to the standard ways of treating copper-resource data and presenting results of analysis. Pioneering work on such alternatives, carried out by the Canadian Department of Energy, Mines, and Resources (Zwartendyk, 1974; Martin and others, 1976) has provided valuable stimulus to this study.

The reader of this report will find useful a general knowledge of the geology of copper deposits, such as is reviewed in Titley and Hicks (1966), Cox and others (1973), Singer and others (1975), and Tourtelot and Vine (1976). The history of development of the U.S. coppermining industry, as described by Parsons (1933) and Joralmon (1973), is also useful as background information.

\section{ACKNOWLEDGMENTS}

The authors wish to thank Donald A. Singer, John H. DeYoung, Jr., Ted G. Theodore, Robert Gordon Schmidt, William J. Moore, Edward M. MacKevett, Jr., and S. Cyrus Creasey of the U.S. Geological Survey, and John D. Morgan, Jr., Harold J. Schroeder, and Harold J. Bennett of the U.S. Bureau of Mines for contributions to data on which this study was based, as well as for valuable discussion and criticism. We also acknowledge the cooperation of industry geologists, too numerous to mention, who have contributed information used in this study. 


\section{DEFINITIONS OF TERMS}

Reserve and resource terminology has been standardized by the U.S. Bureau of Mines and the U.S. Geological Survey (1980). The definitions as they apply to copper are as follows:

Resource. A concentration of naturally occurring copper in or on the Earth's crust in such form and amount that economic extraction from the concentration is currently or potentially feasible.

Identified resources. Copper resources whose location, quality, and quantity are known or estimated from physical measurements or are inferred from geologic evidence.

Undiscovered resources. Copper resources, the existence of which are only postulated, comprising deposits that are separate from identified resources.

Reserve base. That part of identified resources whose location, quality, and quantity are known or estimated from physical measurements.

Reserve. That part of the reserve base that could be economically extracted or produced at the time of determination.

Usage within the copper industry differs from the foregoing definitions. An informal canvas of eight mining company chief geologists and consultants (J. J. Hemley, written commun., 1978) revealed that the term "reserve" is used for any deposit whose location, quality, and quantity are known. Those reserves that have been determined to be economic are termed "economic reserves." Those reserves for which such a determination has not been made are called "geologic reserves." In this study, the following terms are equivalent.

U.S. Bureau of Mines and U.S. Geological Survey

Identified resource

Reserve

Industry usage

Geologic reserve

Economic reserve

Other terms used in this study deal with measurements of the copper content of rock. These include the following:

Ore. Copper-bearing rock that meets the criteria of reserves.

Grade. The copper content, in weight percent, of a body of rock or ore in the Earth.

Cutoff grade. The lowest grade of ore that can be economically mined and milled in a specific deposit; that is, the lowest grade of ore that can be included in a reserve estimate.

Yield. The net quantity of copper produced expressed as a percentage of ore mined, allowing for losses in mining and processing.

Two classes of copper production are considered:

Primary copper. That part of total production or consumption derived from mining.
Secondary copper. That part of total production or consumption derived from recycling of various forms of scrap.

Four main geologic types of copper deposits are referred to in this report:

Porphyry-copper deposits. Masses of rock, tens of millions to billions of tons each, containing copper and molybdenum sulfides in closely spaced veinlets or in disseminated small grains. The deposits are irregular to roughly cylindrical and are in most places associated with an intrusive igneous rock that has a porphyritic texture.

Massive sulfide deposits. Deposits of compact massive copper, iron, zinc, and lead sulfide, and associated disseminated sulfide, having tonnages on the order of tens of millions of tons. These deposits have tabular or podlike form and are interlayered with marine volcanic and sedimentary rocks.

Sedimentary deposits. Layers of sandstone or shale containing disseminated copper minerals and, commonly, valuable amounts of silver.

Copper-nickel deposits. Disseminated or compact masses of copper and nickel sulfide in mafic igneous intrusions.

\section{SOURCES OF DATA AND METHODS OF ANALYSIS}

Data on copper-ore reserves were taken mainly from Metals Sourcebook, a former bimonthly publication of McGraw Hill Company, and Mining Annual Review, an annual publication of Mining Journal. These publications summarize information from other miningindustry periodicals and company annual reports. Company prospectuses, prepared in compliance with the U.S. Securities and Exchange Commission, also were consulted for reserve data on several major deposits. Data on total past production were taken mainly from geologic reports on deposits discussed in Titley and Hicks (1966), Ridge (1968), and other publications too numerous to be named here. Data on current annual production were mainly from Mining Annual Review and company annual reports. All data in this report were collected before January 1, 1979.

Quantitative data are presented in English and metric units in tables and figures and in English units in the discussion sections. English units are used because of U.S. industry usage and because U.S. Bureau of Mines reserve data are in those units. For conversion purposes, 1 metric ton equals 1.101 short tons. Because many of the estimates are not precise, metric and English units expressed in tons are for practical purposes interchangeable.

Analysis of data for this paper was assisted by the use of the Computerized Resource Information Bank (CRIB) of the U.S. Geological Survey and by the Minerals Availability System (MAS) of the U.S. Bureau of 
Mines. CRIB is a computer file that contains location, exploration, mineralization, deposit-description, and geological and mineralogical information on many mineralized areas. The data file used in this study, a subset of CRIB, is accéssed by the Geologic Retrieval and Synopsis Program (GRASP) (Bowen and Botbol, 1975). GRASP allows the user to retrieve data on selected copper deposits on the basis of given conditions and statistically to analyze and test the reliability of the data. Computer programs that use the copper file have been written to calculate estimated depletion dates or to determine the total production capacity of copper in the United States for any years of interest.

The Minerals Availability System (MAS) was established to determine the availability of minerals to the United States from known domestic and foreign sources and to express this potential supply as a function of cost relative to time. In the process of identifying and evaluating significant mineral deposits, MAS is capable of analyzing the conditions that influence the use of minerals and of evaluating current technology as applied to the development of the reserve or resource. It can develop and cost related mining and processing systems using the MINSIM 4 financial-analysis program, and can perform financial analysis; it can be used to conduct comprehensive availability studies. An early version of the financial-analysis methodology was described by Bennett and others (1970).

\section{RESERVE DATA}

Ore-reserve estimates for selected U.S. deposits are shown in table 1. In interpreting the significance of such published reserve data, the reader should be aware of three facts. First, published copper-reserve figures frequently represent the total amount of copper contained in situ, and only a certain amount of these reserves is recoverable and will ultimately enter into the available supply. Second, the value of associated metals is important in the economics of copper reserves. Third, mining companies tend to be conservative in publishing reserve figures, and these figures should be considered as describing a minimum available supply.

TABLE 1.-Published reserves and resources of copper in the United States [From sources available as of January 1977; data in thousand short tons]

\begin{tabular}{|c|c|c|c|c|c|c|c|}
\hline Deposit name & Company & $\begin{array}{l}\text { Type of } \\
\text { deposit }\end{array}$ & Ore & $\begin{array}{c}\text { Grade } \\
\text { (percent copper) }\end{array}$ & $\begin{array}{l}\text { Copper } \\
\text { content }\end{array}$ & $\begin{array}{l}\text { Associated } \\
\text { metals }\end{array}$ & Reference \\
\hline
\end{tabular}

A. RESERVES IN OPERATING MINES AND ANNOUNCED DEVELOPMENTS

\begin{tabular}{c}
\hline Twin Buttes \\
Do
\end{tabular}

$\begin{array}{ll}\text { OP-P } & 344,000 \\ & { }_{2} 62,000\end{array}$

Arizona

0.71

0.71

2,445

\section{Mission \\ Sacaton, West \\ Sacaton, East \\ San Xavier Do \\ Silver Beill}

Palo Verde (1978)

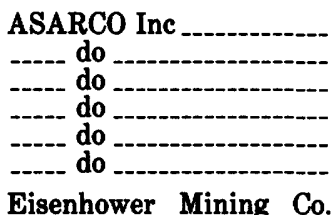

(ASARCO-ANAMAX).

Pinto Valley

Cities Service Co.

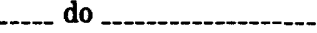

Oracle Ridge/Control.

Bagdad<smiles></smiles>

Do

Bruce

Johnson

Esperanza

Sierrita

Mineral Park.---

Inspiration (includes Live Oak

Thornton, and

Red Hill Mines).

Christmas

Do

Ox Hide
Continental Materials

$$
\text { Corp. (Union Minière, }
$$
45 percent interest)

Cyprus Mines Corp -....-.

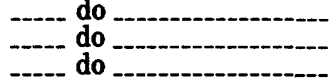

--.-- do

Duval Corp. (Pennzoil

Co.).

Inspiration Consolidated Copper $\mathrm{Co}$.

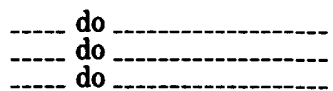

----- do

\section{OP-P $\quad 87,100$}

OP-P $\quad 32,700$

UG-P $\quad 16,700$

OP-P 152,100

OP-P $\quad 27,900$

OP-P $\quad 29,700$

OP-P $\quad 125,000$

.68
.74
1.23
.51
1.06
.66
.57

\section{2}

542

205

776
84

196

713

.57

713

$\begin{array}{rrrrr}\text { OP-P } & 350,000 & .44 & 1,540 & \ldots \\ \text { P } & & & & \\ \text { P } & 11,300 & 2.28 & 257 & .64 \mathrm{oz} . \mathrm{Ag} \text {...- }\end{array}$

$\begin{array}{llll}\text { OP-P } \quad 297,000 & .49 & 1,455\end{array}$

${ }^{2} 28,000$

${ }^{3} 88,000$

$\begin{array}{lr}\text { UG-M } & 195 \\ \text { OP-P } & 213,000\end{array}$

OP-P $\quad 31,000$

OP-P $\quad 523,000$

$\begin{array}{lr}\text { OP-P } & 523,000 \\ \text { OP-P } & 60,000\end{array}$

OP-P ${ }^{4} 189,000$

.49
.22
3.65
.50
.40
.32
.29
4.50

194
7

7
65

125

1,672

1,672
175

943

$\begin{array}{ll}\text { OP-P } & { }^{4} 25,200 \\ \text { UG-P } & { }^{4} 56,800\end{array}$

$\begin{array}{ll}\text { UG-P } & { }^{4} 56,800 \\ \text { OP-P } & 49,000\end{array}$
Ag, Mo

Ag

-

A

$\mathrm{Ag}, \mathrm{Mo}$

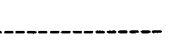

Ag, Mo

0.03 percent $\mathrm{M}$

Mo Sec

Commission,(SEC), merger registration Form S-14 No. 2-52105, Atlantic Richfield Co. (ARCO) and The Anaconda Co., Sept. 14, 1976.

ASARCO Incorp., Prospectus on debenture offering of May 7, 1975. SEC file No. 1-164.

ARC0-Anaconda merger, SEC filing Sept. 14, 1976 . ASARCO, 3rd Quarter 1976, Report to Stockholders.

Cities Service Co., Preliminary prospectus, June 24 , 1975.

Engineering \& Mining Journal, v. 176, No. 4, April 1975, page 170.

-.- Annual Report, SEC

12.9-percent $\mathrm{Zn}$

-.--.-.-.-

Mo

.036-percent Mo

Mo

Form 10-K filed March 30, 1976.

Pennzoil, 1975, Annual Report.

Inspiration Consolidated Copper Co., 1975, Annual Report. Recoverable copper reported. 
TABLE 1.-Published reserves and resources of copper in the United States-Continued

\begin{tabular}{ccccccc}
\hline Deposit name & Company & $\begin{array}{c}\text { Type of } \\
\text { deposit }^{1}\end{array}$ & Ore & $\begin{array}{c}\text { Grade } \\
\text { (percent copper) }\end{array}$ & $\begin{array}{c}\text { Copper } \\
\text { content }\end{array}$ & $\begin{array}{c}\text { Associated } \\
\text { metals }\end{array}$ \\
\hline
\end{tabular}

A. RESERVES IN OPERATING MINES AND ANNOUNCED DEVELOPMENTS-Continued Arizona-Continued

\begin{tabular}{llllllll}
\hline Ray -1 & Kennecott Copper Corp_- & OP-P & 667,000 & .79 & 4,400 & Mo
\end{tabular}

San Manuel Kala- Magma Copper Co. (Newmazoo.

Magma/Superior

Morenci

Metcalf Cornelia (Ajo)

Bluebird

Pl
mont Mining $\mathrm{Co}$.). do Phelps Dodge Corp

-.-.- do -.-.- do

Ranchers Exploration \& Development Co.

$\begin{array}{rrrr}\text { UG-P } & 1,000,000 & .70 & 7,000 \\ \text { UG-0 } & 10,000 & 4.50 & 450 \\ \text { OP-P } & 662,500 & .80 & 5,300 \\ \text { OP-P } & 416,000 & .77 & 3,200 \\ \text { OP-P } & 126,600 & .63 & 798 \\ \text { OP-P } & { }^{2} 75,000 & .50 & 375\end{array}$

Reserves at 75.9 percent recovery. Excludes copper recoverable from waste dump leaching. Kennecott Copper Corp., Letter to stockholders, Nov. 26, 1976.

"Magma Facts," Magma Copper Co., Oct. 1, 1976.

+0.03-percent

Phelps Dodge Corp., Prospectus, SEC File 1-82, May 22, 1975.

Ranchers Exploration \& Development Corp., 1974 annual report. Form 10K SEC File 1-6367, Sept. 30,1975 .

\begin{tabular}{|c|c|c|c|c|c|c|c|}
\hline \multicolumn{8}{|c|}{ Michigan } \\
\hline White Pine & Copper Range & UG-S & ${ }^{5} 405,000$ & 1.23 & 4,981 & $0.16 \mathrm{oz} . \mathrm{Ag}$ & Copper Range, 1975, Annu- \\
\hline $\begin{array}{l}\text { Do } \\
\text { Do }\end{array}$ & -- do & $\begin{array}{l}\text { UG-S } \\
\text { UG-S }\end{array}$ & $\begin{array}{r}6 \\
694,000 \\
{ }^{6} 128,000\end{array}$ & $\begin{array}{l}1.20 \\
1.06\end{array}$ & $\begin{array}{l}1,227 \\
1,361\end{array}$ & - & \\
\hline \multicolumn{8}{|c|}{ Montana } \\
\hline $\begin{array}{l}\text { Berkeley } \\
\text { Continental area_ } \\
\text { Continental } \\
\text { (North, Center, } \\
\text { West). }\end{array}$ & \begin{tabular}{l} 
The Anaconda Co \\
\hdashline-10 \\
-
\end{tabular} & $\begin{array}{l}\text { OP-P } \\
\text { OP-P } \\
\text { OP-P }\end{array}$ & $\begin{array}{r}152,000 \\
17,000 \\
253,000\end{array}$ & $\begin{array}{l}.67 \\
.49 \\
.60\end{array}$ & $\begin{array}{r}1,018 \\
83 \\
1,518\end{array}$ & - & $\begin{array}{l}\text { ARCO/Anaconda, Merger } \\
\text { Filing. }\end{array}$ \\
\hline $\begin{array}{l}\text { Battle Mountain } \\
\text { (includes Cop- } \\
\text { per Basin and } \\
\text { Copper Can- } \\
\text { yon). }\end{array}$ & Duval Corp., Pennzoil _.-- & OP-P & 7,300 & .63 & 46 & ---- & $\begin{array}{l}\text { Pennzoil, 1975, Annual Re- } \\
\text { port. }\end{array}$ \\
\hline Ruth/Ely & Kennecott Copper Corp_- & OP-P & 29,330 & .79 & 185 & Mo & $\begin{array}{l}\text { Kennecott, Prospectus } \\
\text { April 15, 1971. Reserves } \\
\text { at 74.7 percent recovery, } \\
\text { adjusted for production } \\
\text { shown in 1971-75 annual } \\
\text { reports. }\end{array}$ \\
\hline
\end{tabular}

New Mexico

$\begin{array}{lllllll}\text { Chino/Santa Rita } & \text { Kennecott Copper Corp }- & \text { OP-P } & 443,000 & 0.73 & 2,400 & \text { Mo }\end{array}$

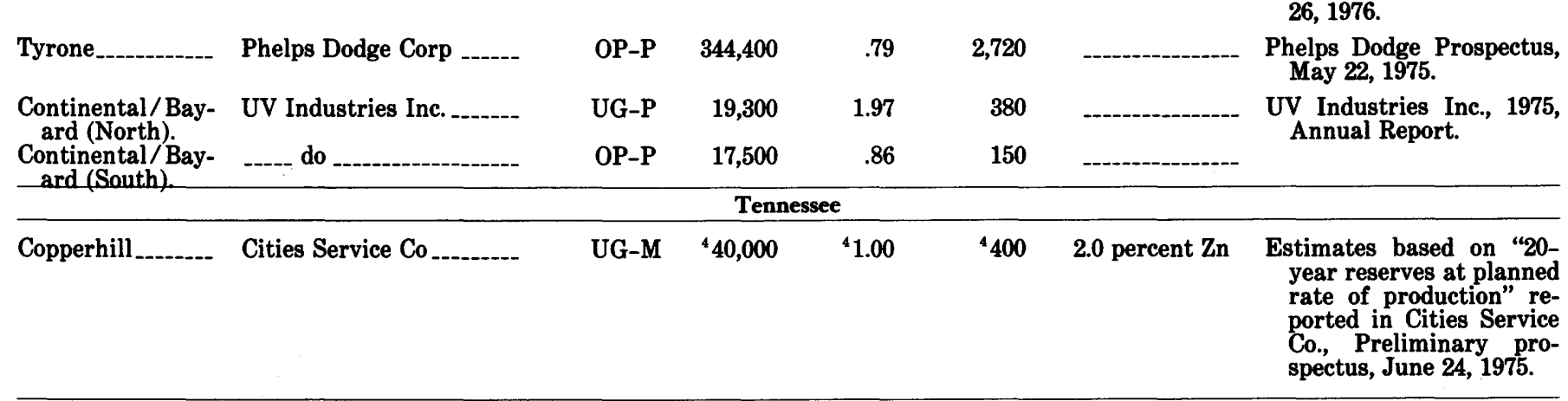

\begin{tabular}{llllll}
\hline \multicolumn{7}{c}{ Utah } \\
\hline Carr Fork _-1-- The Anaconda Co & UG-P & 61,200 & 1.84 & 1,126 & -
\end{tabular}


THE NATURE AND USE OF COPPER RESERVE AND RESOURCE DATA

TABLE 1.-Published reserves and resources of copper in the United States-Continued

\begin{tabular}{|c|c|c|c|c|c|c|c|}
\hline Deposit name & Company & $\begin{array}{l}\text { Type of } \\
\text { deposit }^{1}\end{array}$ & Ore & $\begin{array}{c}\text { Grade } \\
\text { (percent copper) }\end{array}$ & $\begin{array}{r}\text { Copper } \\
\text { content }\end{array}$ & $\begin{array}{c}\text { Associated } \\
\text { metals }\end{array}$ & Reference \\
\hline \multicolumn{8}{|c|}{$\begin{array}{l}\text { A. RESERVES IN OPERATING MINES AND ANNOUNCED DEVELOPMENTS-Continued } \\
\text { Utah-Continued }\end{array}$} \\
\hline $\begin{array}{l}\text { Bingham/Utah } \\
\text { Copper }\end{array}$ & Kennecott Copper Corp_- & OP-P & $1,602,000$ & .70 & 9,500 & $\mathbf{M o}, \mathbf{A u}, \mathbf{A g}$ & $\begin{array}{l}\text { Reserves at } 84.7 \text { percent re- } \\
\text { covery. Excludes copper } \\
\text { recoverable from waste- } \\
\text { dump leaching. Kenne- } \\
\text { cott Copper Corp., Letter } \\
\text { to stockholders, Nov. 26, } \\
1976 .\end{array}$ \\
\hline
\end{tabular}

B. IDENTIFIED RESOURCES IN UNDEVELOPED DEPOSITS AND CLOSED MINES

\begin{tabular}{|c|c|c|c|c|c|}
\hline & & \multicolumn{4}{|c|}{ Arizona } \\
\hline Helvetia-East/ & ANAMAX Mining Co & $\mathbf{P}$ & ${ }^{2} 22,000$ & .55 & 121 \\
\hline Helvetia-East/ & --_- do & $\mathbf{P}$ & 337,000 & .54 & 1,820 \\
\hline Helvetia-West _.. & ...-. do _ & $\mathbf{P}$ & ${ }^{7} 24,000$ & .75 & 180 \\
\hline Lakeshore & $\begin{array}{l}\text { Hecla Mining Co., and El } \\
\text { Paso Natural Gas Co. }\end{array}$ & UG-P & 470,000 & .75 & 3,500 \\
\hline
\end{tabular}

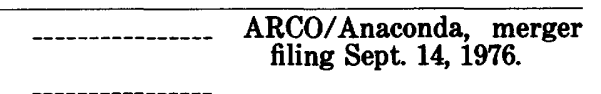

RCO/Anaconda, merger

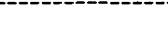

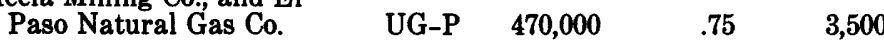

Miami East

Cities Service Co

UG-P $\quad 55,000$

1.95

1,073

Pima

do

OP-P $\quad 181,000$

.49

887

Ag, Mo

$\begin{array}{llll}\text { UG-P } & 250,000 & 1.0 & 2,500\end{array}$

Coastal Mining Co. (Getty

Oil Co., Hanna Mining

Co.) --_-_-

Buttes.

Sanchez (Safford) Inspiration Consolidated Copper Co.

Safford

Phelps Dodge Corp

Copper Basin

Old Reliable Mine

$\begin{array}{rrrrr}\text { OP-P } & 800,000 & .4 & 3,200 & - \\ & & & & \\ \text { P } & 200,000 & .4 & 800 & - \\ & & & & \\ \text { UG-P } & 400,000 & .72 & 2,800 & - \\ \text { P } & 175,000 & .55 & 963 & \begin{array}{l}.02-\text { percent Mo } \\ \text { P/UG-P }\end{array} \\ 4,000 & .74 & 10 & .02 \text {-percent Mo }\end{array}$

Hecla Mining Co., 1969, Annual Report. Reserves include tactite, oxide, and disseminated, unchanged through 1976.

Cities Service Co., Preliminary prospectus, June 24 , 1976.

Cyprus Mines Corp., Annual Report, 1975. SEC Form 10-K filed March 30, 1976.

Mining Magazine, Jan. 1977, p. 47 (Mining Engineering, Nov. 1976, p. 15).

Skillings Mining Review, Jan. 17, 1976, p. 6.

Inspiration, 1975, Annual Report.

Phelps Dodge, Prospectus, May 22, 1975.

Reserves in Recoverable Copper, Ranchers 197475, Annual Report, Form 10-K, Sept. 30, 1975. do

Ranchers Exploration \& Development Co.

\begin{tabular}{lllllll}
\hline & \multicolumn{7}{c}{ Maine } \\
\hline $\begin{array}{l}\text { Bluehill/ } \\
\text { Blackhawk. }\end{array}$ & Kerr Addison Co ------ & UG-M & 520 & 1.46 & 8 & 3.4-percent Zn $\begin{array}{c}\text { Noranda Mines Ltd., 1975, } \\
\text { Annual Report. }\end{array}$ \\
\hline
\end{tabular}

\begin{tabular}{|c|c|c|c|c|c|c|c|}
\hline \multicolumn{8}{|c|}{ Michigan } \\
\hline $\begin{array}{l}\text { Western Syncline } \\
\text { White Pine Dis- } \\
\text { trict. }\end{array}$ & $\begin{array}{l}\text { AMAX Inc } \\
\text { do }\end{array}$ & $\begin{array}{l}\text { SS } \\
\text { SS }\end{array}$ & $\begin{array}{r}105,000 \\
62,000\end{array}$ & $\begin{array}{l}1.3 \\
1.35\end{array}$ & $\begin{array}{r}1,365 \\
840\end{array}$ & - & $\begin{array}{r}\text { SEC merger registration } \\
\text { Form S-14 No. 2-54286, } \\
\text { AMAX, Inc., and Copper } \\
\text { Range Co., July } 29,1975 .\end{array}$ \\
\hline
\end{tabular}

Minnesota

\begin{tabular}{|c|c|c|c|c|c|c|c|}
\hline $\begin{array}{l}\text { Babbit Lake } \\
\text { Ely/Spruce Rd }\end{array}$ & $\begin{array}{l}\text { AMAX Inc } \\
\text { Inco Ltd }\end{array}$ & $\begin{array}{l}\mathrm{CuNi} \\
\mathrm{CuNi}\end{array}$ & $\begin{array}{r}100,000 \\
{ }^{4} 100,000\end{array}$ & $\begin{array}{r}.9 \\
4.9\end{array}$ & $\begin{array}{r}770 \\
1,000\end{array}$ & $\begin{array}{l}0.4 \text {-percent } \mathrm{Ni} \\
.25 \text {-percent } \mathrm{Ni}\end{array}$ & $\begin{array}{l}\text { Skillings Mining Review, } \\
\text { July 19, } 1975 .\end{array}$ \\
\hline
\end{tabular}

\begin{tabular}{|c|c|c|c|c|c|c|c|}
\hline \multicolumn{8}{|c|}{ Montana } \\
\hline $\begin{array}{l}\text { Butte District }(9+ \\
\text { deposits). } \\
\text { Heddleston } \\
\text { Stillwater }\end{array}$ & 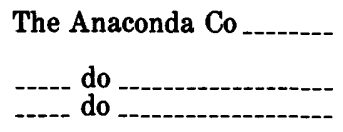 & $\begin{array}{l}\text { UG-P } \\
\text { and vein } \\
\underset{\mathrm{CuNi}}{\mathrm{P}}\end{array}$ & $\begin{array}{r}1,679,000 \\
93,000 \\
151,000\end{array}$ & $\begin{array}{l}.72 \text { avg. } \\
.48 \\
.25\end{array}$ & $\begin{array}{c}12,068+ \\
446 \\
378\end{array}$ & $\begin{array}{l}\mathrm{Mo}, \mathrm{Ag}, \mathrm{Zn} \\
.02 \text {-percent } \mathrm{Mo} \\
.25 \text {-percent Ni }\end{array}$ & $\begin{array}{l}\text { ARCO/Anaconda, merger } \\
\text { filing, Sept. 14,1976. }\end{array}$ \\
\hline \multicolumn{8}{|c|}{ Nevada } \\
\hline Victoria ----.-- & The Anaconda Co & OP/UG-P & 1,900 & 2.37 & 45 & -- & $\begin{array}{l}\text { ARCO/Anaconda, merger } \\
\text { filing. }\end{array}$ \\
\hline $\begin{array}{l}\text { Yerington District: } \\
\text { Yerington }\end{array}$ & ----- do & OP-P & ${ }^{2} 22,400$ & .32 & 77 & $-\cdots-$ & $\begin{array}{l}\text { ARCO/Anaconda, merger } \\
\text { filing, Sept. 14, } 1976 .\end{array}$ \\
\hline MacArthur & --- do & & 13,000 & .43 & 56 & ---- & \\
\hline
\end{tabular}


TABLE 1.-Published reserves and resources of copper in the United States-Continued

\begin{tabular}{|c|c|c|c|c|c|c|c|}
\hline Deposit name & Company & $\begin{array}{l}\text { Type of } \\
\text { deposit }^{1}\end{array}$ & Ore & $\begin{array}{c}\text { Grade } \\
\text { (percent copper) }\end{array}$ & $\begin{array}{l}\text { Copper } \\
\text { content }\end{array}$ & $\begin{array}{c}\text { Associated } \\
\text { metals }\end{array}$ & Reference \\
\hline & B. IDENTIFIED RESOUR & S IN UN & $\begin{array}{l}\text { EVELOPI } \\
\text { Nevada- }\end{array}$ & $\begin{array}{l}\text { DEPOSITS } \\
\text { ntinued }\end{array}$ & AND CL & D MINES-C & inued \\
\hline $\begin{array}{l}\text { Ann Mason } \\
\text { Lyon }\end{array}$ & $\begin{array}{l}\text { The Anaconda Co. } \\
\text { Anaconda/U.S. Steel }\end{array}$ & UG-P & $\begin{array}{r}495,000 \\
32,000\end{array}$ & $\begin{array}{r}.41 \\
1.22\end{array}$ & $\begin{array}{r}2,029 \\
390\end{array}$ & |- & \multirow{2}{*}{$\begin{array}{l}\text { ARCO/Anaconda, merger } \\
\text { filling, Sept. 14, } 1976 .\end{array}$} \\
\hline $\begin{array}{l}\text { Bear } \\
\text { Hall }-. . . .-\end{array}$ & $\begin{array}{l}\text { The Anaconda Co } \\
\text { do }\end{array}$ & $\begin{array}{l}\mathbf{P} \\
\mathbf{P}\end{array}$ & $\begin{array}{r}500,000 \\
54,000\end{array}$ & $\begin{array}{l}.40 \\
.46\end{array}$ & $\begin{array}{r}2,000 \\
248\end{array}$ & $\begin{array}{l}\text { Mo, Au, Ag } \\
52 \text { million tons } \\
0.19 \text {-percent } \\
\text { Mo }\end{array}$ & \\
\hline
\end{tabular}

\begin{tabular}{|c|c|c|c|c|c|c|c|}
\hline \multicolumn{8}{|c|}{ Wisconsin } \\
\hline Crandon & Exxon & UG-M & 60,000 & 1.00 & 600 & 6.5-percent $\mathrm{Zn}$ & $\begin{array}{l}\text { The Capital Times, Mad- } \\
\text { ison, Wisc., Sept. } 8,1976 \text {, } \\
\text { p. } 29 \text {. }\end{array}$ \\
\hline $\begin{array}{l}\text { Ladysmith/ } \\
\text { Flambeau. }\end{array}$ & Kennecott & OP-M & 11,000 & 4.0 & 450 & --- & $\begin{array}{l}\text { Skillings Mining Review, } \\
\text { April 10, 1976. }\end{array}$ \\
\hline
\end{tabular}

${ }^{1}$ Mining method: OP, open pit, and UG, underground. Geological type: $P$, porphyry, includes disseminated, stockwork, and skarn; SS, stratabound sedimentary; $M$, massive sulfide including volcanogenic deposits; $\mathrm{Cu}-\mathrm{Ni}$, magmatic copper-nickel deposits; 0 , other types.

${ }^{2}$ Oxide-ore reserve.

stockpiled oxide ore. Acid soluble copper content shown.

Estimate.

'In situ and undiluted resource. Not included in total.

- Reserves at 57-percent extraction and 9-percent dilution.

${ }^{\top}$ Mixed oxide and sulfide reserves.

Losses take place at nearly all stages of mining and processing. Good industry-wide data on mining losses are not available, but as an extreme example of such a loss, in the sedimentary copper deposit at White Pine, Mich., only 52 percent of a mineable reserve block is extracted because of the layered form of the ore deposit and the mining methods used. In the large open-pit mines on porphyry deposits, however, dilution and losses during mining are less significant. Greenspoon and Morning (1976) showed that, in 1975, 82 percent of the contained copper was recovered from the milling and flotation of copper and copper-molybdenum ores treated in the United States. An additional 4 percent of the contained copper in concentrates is lost during smelting, and negligible amounts are lost at the refining stage. The net result is that less than 79 percent of the in-ground copper reserves is eventually converted to usable refined copper. Losses are also substantial in the recovery of copper by in-situ and dump leaching of oxide ores. A partial offset to reserves lost in mining and processing is provided by copper recovered in leaching of waste rock containing copper and in-situ leaching of mined underground workings; such recoveries amounted to 9 percent of copper-mine production in 1977.

Coproducts, such as molybdenum, gold, or silver, can be important in making a particularly low-grade copper deposit economic. For example, the Sierrita porphyrycopper mine in Arizona at the end of 1975 contained 523 million tons of ore reserve, which had an average grade of 0.32 percent copper and 0.033 percent molybdenum per ton. At a price of $\$ 0.70$ per pound for copper and $\$ 3.20$ per pound for molybdenum, the 0.033 percent of molybdenum in the ore can generate a value equivalent to 0.15 percent copper. This gives the Sierrita deposit a "copper equivalent" reserve grade of 0.47 percent copper, which can be increased further when gold and silver byproduct credits are considered. In this study, only actual copper content was considered in the calculations.

Considerable uncertainty exists in any reserve estimate. Even for a single deposit under static economic conditions, two firms may make estimates differing by 50 percent or more. Several sources of underestimations can be recognized. Conservative (too low) estimates result from incomplete exploration of a deposit. Data on the subsurface extent of a mineral deposit are acquired by drilling or tunneling. These activities are very costly, and sound economic reasoning demands that they not be undertaken until the information is needed. Exploration expenditures are thus made at a rate adequate for an assured production, and the true tonnages of many deposits are not known until the deposits are in the last stages of being explored. Reserves and production data for the Bingham porphyry-copper deposit are excellent examples of this type of underestimate. A reserve estimate for Bingham in 1930 shows approximately half the present reserve (Committee on Mineral Resources and the Environment, 1975). Another source of underestimation results from the existence of State and local taxes on reserves. Exploration efforts may be limited in order to show a reserve large enough to attract financing but not so large as to invite excessive taxation. The effect of these types of underestimation may be large relative to a national reserve estimate. Because the tonnage of total ore in copper deposits is distributed lognormally (Singer and others, 1975), the largest deposits contain copper in amounts an order of magnitude more than the mean. Thus, an error in the estimate for the largest deposit may seriously affect the national estimate. 
Some of these errors have been reduced because in recent years mining firms have tended to drill out and evaluate deposits fully and have initially designed the pit or underground mine to extract most of the ore body. In addition, most of the very large deposits were developed in the early part of this century and now are fairly well understood and their total dimensions known.

Most important, the national-reserve estimate now tends to be overestimated, at least temporarily. Since 1972 , inflation has caused mine and mill operating costs to rise more than 50 percent, whereas copper prices have stayed low because of large worldwide inventories. More than a third of the U.S. copper mines operated in 1975 at costs per pound equal to or above the average annual copper price of 64.5 cents per pound. During such periods of low copper prices, operators of unprofitable mines who stay in production can be assumed to do so because they anticipate a resumption of more favorable price-cost ratios and are avoiding the high costs of closing and reopening their operations. Thus, even by restricting our usage of the term "reserve" to ore in operating mines, we are still uncertain how much of this ore is being extracted profitably and can be defined as reserves in the strict sense. If we use a somewhat more flexible approach that allows for rapidly changing costs and prices, reserves may be defined by anticipated economic conditions in the near term. Under this definition, most of the operating properties can be considered as having reserves. Moreover, deposits being considered for development may or may not have reserves as defined by anticipated economic conditions at the time they are expected to come into production, usually 4 to 8 years from the time of the decision to develop (Burgin, 1976).

To show the sensitivity of reserves to the economic conditions prevailing at the end of 1975, MAS was used to generate the data shown in table 2. The table lists estimates of the amount of measured and indicated copper reserves, in short tons, recoverable at various price levels and at discounted cash-flow rate of return calculated in terms of 1975 dollars. The rates of return were selected to show reserve levels ranging from a breakeven cost point ( 0 percent) to a profit level of 18 percent.

TABLE 2.-The sensitivity of U.S. copper reserves, in millions of short tons, to economic conditions, in 1975

[Data from H. J. Bennett, written commun., 1977]

\begin{tabular}{crrrrr}
\hline \multirow{2}{*}{$\begin{array}{c}\text { Rate of return } \\
\text { (percent) }\end{array}$} & \multicolumn{5}{c}{$\begin{array}{c}\text { Copper price } \\
\text { (1975 dollars/ton) }\end{array}$} \\
\cline { 2 - 6 } & 0.60 & 0.65 & 0.70 & 0.75 & 0.80 \\
\hline 0 & 82 & 89 & 93 & 102 & 107 \\
\hline $6---$ & 77 & 78 & 85 & 90 & 94 \\
\hline 12 & 76 & 69 & 76 & 80 & 85 \\
\hline 18 & 40 & 47 & 51 & 56 & 74 \\
\hline
\end{tabular}

The national reserve estimate is thus somewhat of a moving target, which is underestimated as a result of inherent economic, geologic, and engineering factors and overestimated as a result of falling price/cost ra- tios. Any reserve estimate must therefore be accompanied by a statement of the assumptions on which it is based. For example, on the basis of data in this report (tables 1, 4), the following two different U.S. reserve estimates can be made: First, recoverable copper in deposits in production in 1977 is estimated at 49 million short tons. This most conservative estimate reflects a lack of confidence in new mine development under conditions of low copper prices and high capital and operating costs prevailing in 1977. It also reflects the loss of copper in the mining, milling, and smelting process. Second, the sum of the reserves in the foregoing category plus reserves in other deposits whose location and geologic, mineralogic, and engineering characteristics are similar to those being mined during the 1970's is estimated at 93 million short tons. This estimate is made on a deposit-by-deposit analysis of the foregoing factors. The deposits included are those that could be readily brought into production by improved economic conditions or as strategic requirements necessitate. This estimate is the one given in such publications of the U.S. Bureau of Mines as Mineral Commodity Profiles (Schroeder, 1977). This estimate includes copper that may be lost in mining and mineral processing but excludes copper recoverable from leaching waste rock, from dumps and from byproduct copper recoverable from noncopper ores.

These two estimates made by empirical methods compare favorably with the estimates generated by using MAS (table 2). The first, conservative, estimate compares with MAS estimates of copper available at $\$ 0.60-\$ 0.70$ per pound at a $12-18$ percent rate of return. The second, more liberal, estimate compares with estimates of copper available at $\$ 0.75$ to more than $\$ 0.80$ per pound and at a 6-12 percent rate of return.

Copper-reserve estimates of the second, more liberal, type that have been made over the past 45 years are shown in figure 1. Figure 1 shows that from 1930 to 1960, reserve estimates equalled about 27-39 times annual production, indicating that, on the average, mining firms performed sufficient exploration to provide a 30-year supply of primary copper. Reserve estimates made since 1960, however, have approached 49-64 times annual production. This increase probably reflects an increased understanding of the magnitude of the earlydiscovered large porphyry deposits, such as Bingham and Morenci, an increased willingness of mining firms to make public their reserves, and an increase in discoveries resulting from heavy investment in exploration during the 1960's. It is interesting to compare historic reserve estimates with a curve representing reserves in operating properties as they are now measured and credited back to the year of first production. This curve, whose derivation will be discussed in a later section, can be thought of as approximating the actual amount of copper available through time in developed deposits. In 


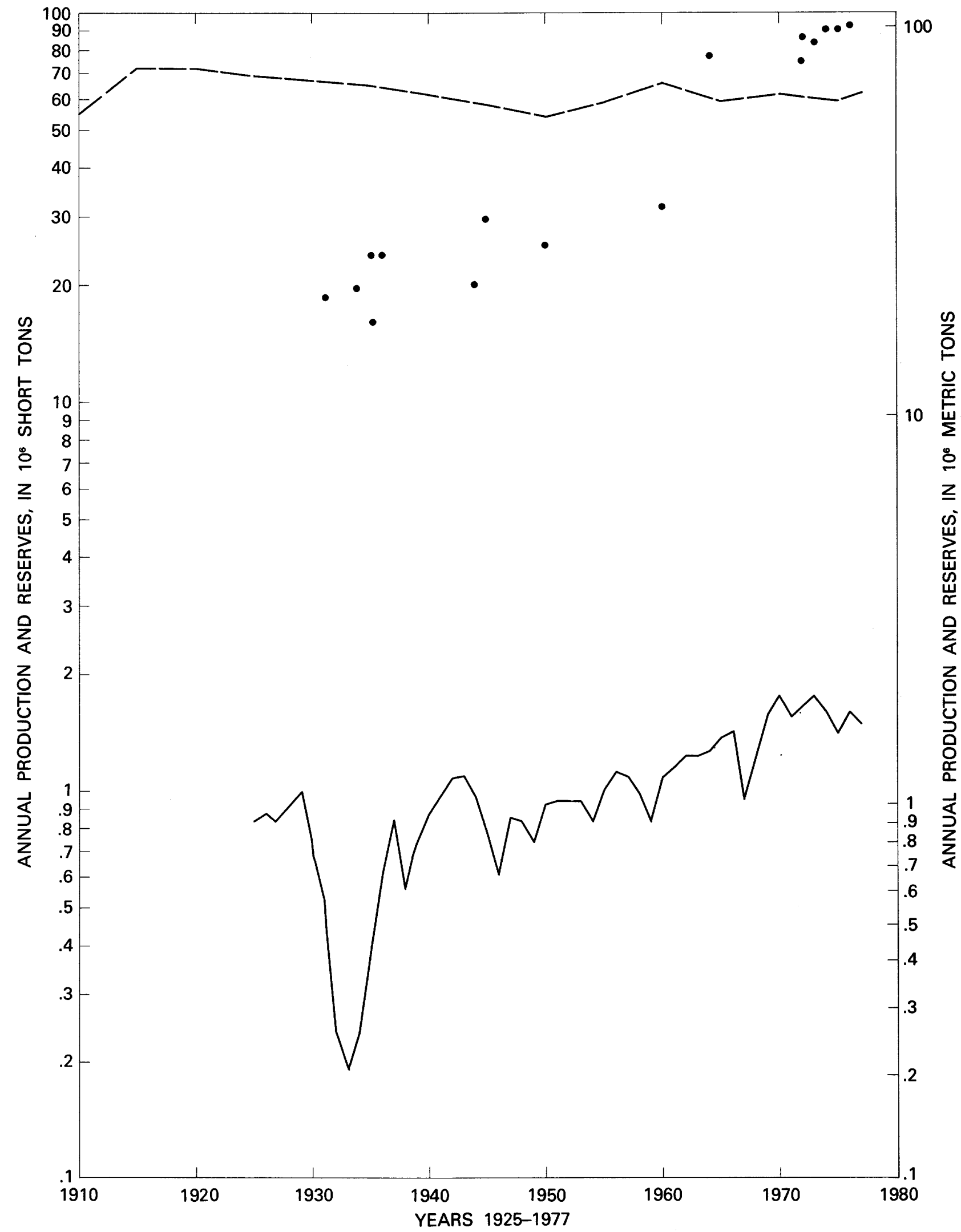

FIGURE 1.-U.S. reserve estimates and annual production 1925-1977. Dots represent historic reserve estimates plotted from Everett and Bennett (1967), Bennett and others (1973), and the U.S. Bureau of Mines (1977). The solid line represents annual production from the U.S. Bureau of Mines Minerals Yearbook. The dashed line represents the actual reserves of operating mines taken from modern data and is calculated from the curves in figure $8 B$. 
the early 1960 's, estimates jumped above this curve as a result of better knowledge and the inclusion of undeveloped properties whose reserves were defined by anticipated economic conditions.

\section{TOTAL ORE AND CONTAINED COPPER}

The sum of reserves and past production yields an estimate of the total ore, total metal contained in ore, and average grade of ore originally in each of the deposits known in the United States. Graphical display of these values (fig. 2) demonstrates the relative magnitude of deposits of various types and facilitates a comparison of the amount of copper in a typical deposit with the annual domestic consumption. Each year, the United States mines the equivalent of all the ore in a large porphyry deposit. A similar chart for worldwide deposits was published by Cox and others (1973) and updated for inclusion in the COMRATE report (Committee on Mineral Resources and the Environment, 1975). These charts clearly reveal that small high-grade deposits, such as those of the massive sulfide type, have contributed little to the national resource total. The very large deposits of this type, of which only a few examples exist, contain about as much copper as a medium-size porphyry deposit. Medium-tonnage massive sulfide deposits contain an order of magnitude less copper. Table 3 summarizes these relationships.

TABLE 3.-Total copper contained in typical deposits [Short or metric tons]

\begin{tabular}{|c|c|c|c|}
\hline Deposit & Small & Medium & Large \\
\hline 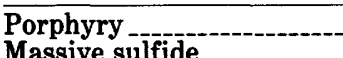 & $\begin{array}{l}10^{5} \\
10^{4}\end{array}$ & $\begin{array}{l}10^{6} \\
10^{5}\end{array}$ & $\begin{array}{l}10^{7} \\
10^{6}\end{array}$ \\
\hline $\begin{array}{l}\text { Massive suinide } \\
\text { Sedimentary }\end{array}$ & $10^{4}$ & $10^{5}$ & $10^{6}$ \\
\hline
\end{tabular}

The values for total ore and total contained metal accurately reflect the extent and intensity of natural mineralizing processes only where all the following conditions hold:

1. The copper grade falls off rapidly at the boundaries of the deposit, so that a lowering of cutoff grade does not substantially change the tonnage.

2. The form and depth of the deposit are such that all of it can be included in a mining plan and thus become an ore reserve.

3. Parts of the deposit were not removed by faulting, erosion, or other postmineralization processes.

Clearly, these three conditions are found in few deposits, so that most estimates of copper contained in ore

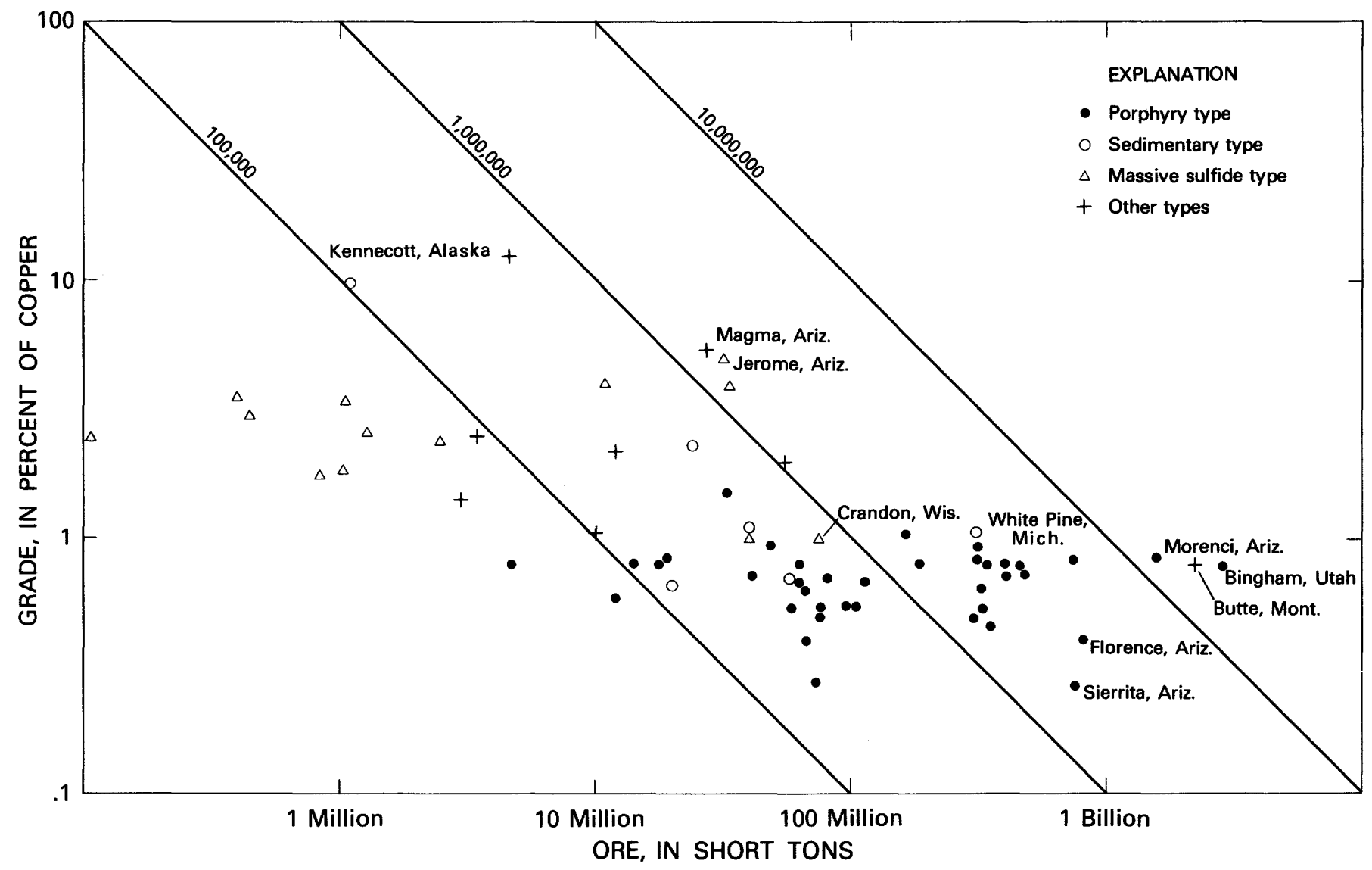

FIGURE 2.-Tonnage and grade of reserves plus past production of U.S. copper deposits. Only published data are shown. Both grade and tonnage scales are logarithmic. Diagonal lines show tons of contained copper in each deposit. 
are low relative to the total copper originally in mineralized rock and estimates may be strongly affected by the economic behavior of mining firms. For this reason, Phillips (1975) has objected to the use of such estimates in making geologic deductions or in estimating the tonnage and grade of undiscovered deposits. A better approximation to the real distribution of copper contained in deposits can be obtained by combining past production with resource estimates (discussed in the following section).

\section{RESOURCE DATA}

Identified resources include mineralized rock that varies greatly in tonnage, metal content, and depth of overburden in widely differing locations. Metal can potentially be won from each deposit classed as an identified resource but at great differences in costs per unit and under widely differing technologic and economic conditions. Consider, for example, $x$ number of tons of copper in mineralized rock in Alaska, $y$ number of tons of metal in a deposit 5,000 ft below the surface in Arizona, and $z$ number of tons of metal in a very low grade deposit for which a metallurgical recovery process is not known. The sum of $x, y$, and $z$ is not a meaningful number because it does not tell the user how much metal could be won if only one or two of the following events were to take place: (1) a road and power network were built in Alaska, (2) an economic-recovery method for deep deposits were devised, or (3) a metallurgical process for low-grade deposits were discovered.

Useful resource estimates should be disaggregated (divided into categories) to the maximum extent permitted by the availability of data (Singer, 1975). A factor limiting disaggregation of data is the requirement that reserve data on certain deposits be kept confidential; data obtained in confidence are aggregated with other data to protect company proprietary interests.

In this study, identified copper resources were classified into seven categories (table 4). Category 1 refers to known resources. Category 2 is composed of deposits similar to those profitably mined during the early 1970's. These deposits would be transferred to the reserve category as soon as a firm announces plans for development.

Category 3 represents a large quantity of copper in resources that are of lower grade than that permitted by the present operation and (or) that require an unevaluated milling technique or represents ores that are deeper or have a higher stripping ratio than do those exploited in the present operation. These resources may be transferred to the reserve category at some future time when ores now being exploited in these deposits become depleted. This category includes about 8 million tons of copper estimated to exist in the White Pine deposit in Michigan in beds that are too thin and (or) too deep for economic mining at present.
Category 4 represents some of the most readily accessible sources of copper, that are in mines that could be

TABLE 4.-Copper resources, in millions of tons, of the United States as of 1978

\begin{tabular}{l} 
Categories \\
\hline 1. Reserves in place in operating mines or in \\
deposits for which development plans \\
have been announced. \\
2. Resources in drilled-out deposits awaiting \\
development. Mainly porphyry deposits \\
in Arizona, New Mexico, Nevada, and \\
Montana. \\
3. Resources in operating mines but not in- \\
cluded in mining plan. Mainly in five of \\
the largest porphyry deposits in Utah, \\
Arizona, and New Mexico and in sedi- \\
mentary deposits in Michigan.
\end{tabular}

4. Resources in mining properties closed since 1974 because of unfavorable economic conditions.

5. Resources in drilled-out deposits at depths requiring high-cost underground mining methods or as yet undeveloped in-place leaching methods; mainly in Arizona and Utah. About half the total is in deposits having grades of more than 0.75 -percent copper.

6. Resources in drilled-out deposits in Washington, Wyoming, Minnesota, and Wisconsin, where environmental restrictions have contributed to delays in development.

7. Resources in drilled-out deposits in remote locations in Alaska. About 60 percent of the total is in deposits that have grades of more than 0.75-percent copper.

\section{List of deposits included in resource categories}

Category 1. Arizona: Ajo, Bagdad, Bluebird, Bruce, Esperanza-Sierrita, Inspiration, Johnson, Magma, Marble Peak, Mineral Park, Mission, Morenci Metcalf, Palo Verde, Pinto Valley, Ray, Socaton, San Manuel-Kalamazoo, San Xavier, Silver Bell, Twin Buttes.

Michigan: White Pine

Montana: Black Pine, Butte-Berkeley.

New Mexico: Chino, Continental-Bayrad, Tyrone.

Nevada: Copper Basin

Tennessee: Ducktown.

Utah: Bingham, Carrfork.

2. Arizona: Cactus, Carpenter, Chilito, Copper Basin, Florence, Helvetia-RoseMont, Miami East, Mineral Butte, Sanchez, Van Dyke, Vekol.

Montana: Heddleston-Lincoln, Spar Lake, Stillwater, Twin Bridges.

Nevada: Ann Mason, Bear, Lyon, MacArthur.

New Mexico: Pinos Altos.

Oklahoma: Mangum.

3. Arizona: Ajo, Christmas, E speranza-Sierrita, Inspiration, Morenci, Ray, San Manual, Silver Bell, Twin Buttes.

Michigan: White Pine.

Montana: Butte.

Nevada: Ely-Ruth.

New Mexico: Chino.

Utah: Bingham.

4. Arizona: Lakeshore, Pima, Christmas, Yerington, Copper Canyon. Nevada: Ely-Ruth, Victoria.

New Mexico: Nacimiento.

Oklahoma: Creta.

5. Arizona: Red Mountain, Safford-Kennecott, Safford-Phelps Dodge, West Casa Grande.

Utah: Tintic South.

6. Minnesota: Babbitt Lake, Ely-Spruce Road. Washington: Flagg Mountain, Glacier Peak, Margaret, North Fork, Sultan. Wisconsin: Crandon, Flambeau, Rhinelander.

Wyoming: Kerwin.

7. Alaska: Arctic Camp, Bornite, Brady Glacier, Horse Creek, Pienic Creek, Orange Hill. 
brought back quickly into production under favorable economic conditions. The longer the period of closure, however, the more difficult it is to reopen the mines because of the dispersal of trained workers to other projects and the inevitable decay of excavation slopes or underground workings.

Category 5 constitutes resources that are most sensitive to the effects of technological development. The role of technological change in the copper industry is difficult to assess. The expectation that technological advances will transform low-quality resources into copper ore has some historical precedent. From 1904 to 1913, the application of large-scale mining machinery and new mineral-concentrating techniques to copper mining made possible large economies of scale (Parsons, 1933; Joralmon, 1973). These permitted a reduction of economic grade from about 6 percent in previously mined vein deposits to 2 percent in large-tonnage porphyry deposits. Since that period, ores of continually declining yield have been profitably mined (fig. 3), testifying to the continuing improvement in mining and beneficiation techniques. The 1904-1913 changes in technology were major breakthroughs; the changes after that period were brought about by fine tuning of existing techniques. For most of the deposits in category 5 to become economically attractive, major technological breakthroughs are required. These breakthroughs must not depend on extravagant uses of energy, because of its rising cost (Rosenkranz, 1976). In-place fracturing and leaching of deposits represent a potential for important technological change, but many problems are still unsolved.

Because deposits in category 5 are low in quality, exploration firms are reluctant to spend the effort necessary to quantify their resources fully. For this reason, large but unknown quantities of copper are excluded from the estimate. Principal among these are resources of native copper in deep extensions of mines closed since the 1950's in the Upper Peninsula of Michigan. These resources could potentially equal in magnitude the quantity shown in category 5.

Category 6 illustrates a recent trend toward increased restrictions on mineral development brought

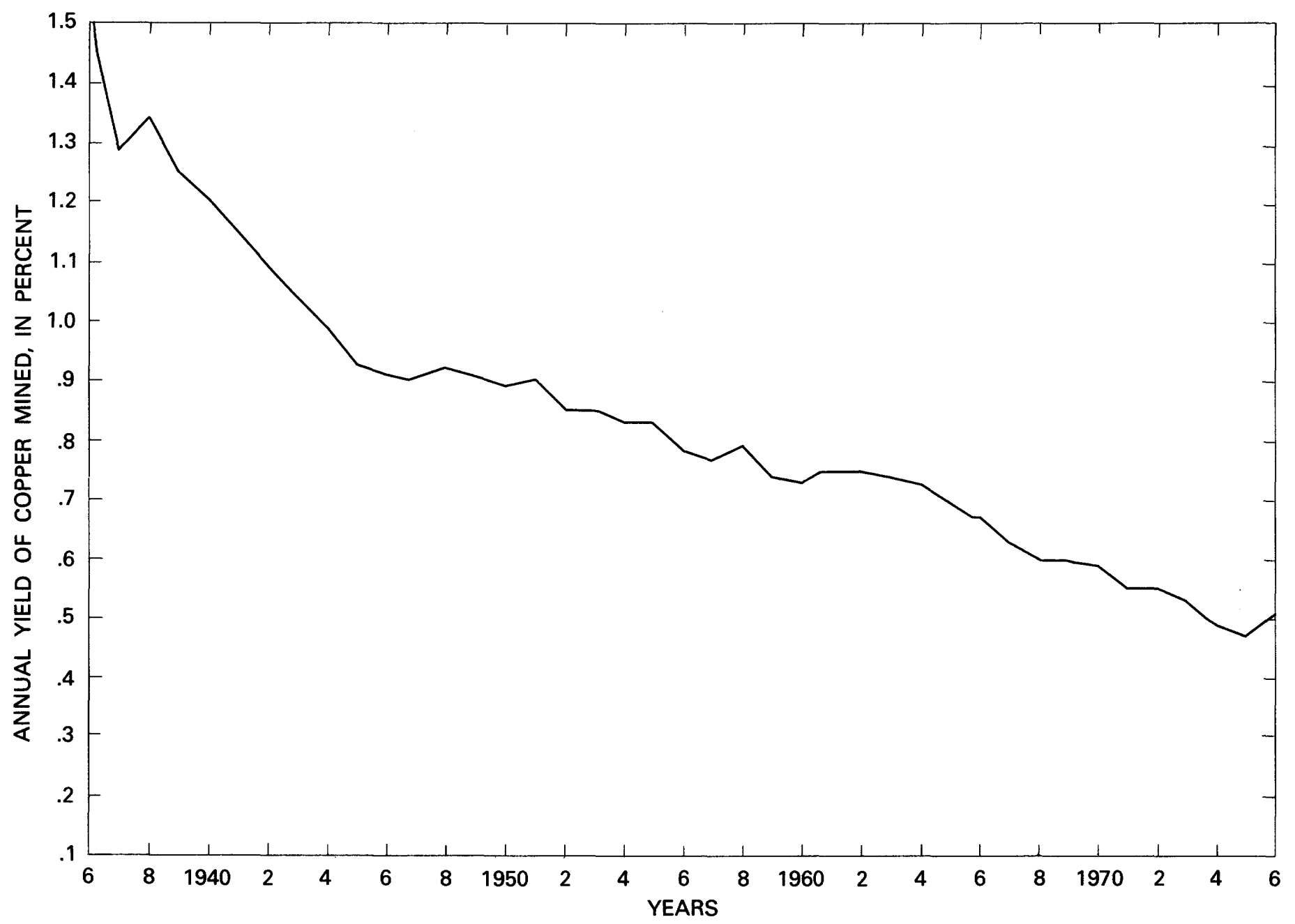

FIGURE 3.-Declining yield (percent of metal produced from ore mined) of U.S. copper mines, 1936-1976. 
about by environmentally concerned groups at the local, State and Federal levels of government. The effects of environmental concern are felt most strongly when new deposits are discovered in regions without longstanding copper-mining traditions. In Minnesota, Washington, Wisconsin, and Wyoming, creative exploration concepts and willingness to apply modern technology to hitherto unexploited deposits (copper-nickel resources near Duluth, Minn.) stimulated investment in new projects in the 1960's and early 1970's. Most of these projects have been abandoned or indefinitely postponed, partly because of unfavorable economic conditions but mainly because of resistance from groups concerned with threatened changes in the natural environment. The resource total for category 6 includes only drilled-out deposits and does not include large resources of copper estimated to exist in the Duluth Complex of Minnesota (Bonnichsen, 1974).

Deposits in Alaska are placed in a separate category (7) because of the special conditions placed on development by their remoteness and by the harshness of the environment. Costs of mining low-grade ores in Alaska in 1973 were 67 percent higher than those for similar deposits in Arizona (Bottge, 1974). Even such a highgrade deposit as Kennecott, which was profitably mined between 1911 and 1938, would be uneconomic under 1973 conditions if the operation had to bear the cost of road construction to the mine site (Maloney and Bottge, 1973).

Figure 4 shows diagrammatically the relative economic feasibility of exploitation and the amount of geologic uncertainty of these categories of identified resources. The figure is based on the resource-classification diagram introduced by McKelvey (1972) and discussed by Schanz (1975) and Brobst (1979). Rectangles of varying sizes have areas proportional to the tonnage estimates in the various categories. These rectangles are arranged vertically with likelihood of future production decreasing downward and uncertainty of the estimate increasing to the right. The arrangement is somewhat subjective, and readers having special knowledge might prefer to shift some of the rectangles up, down, or sideways. The relative position of the rectangles may change with time, depending on breakthroughs in mineral technology and changes in domestic economic conditions and international commodity prices.

Figure 4 differs from McKelvey's original diagram in two ways. First, because a scale is used, no lower or right-hand margin can be drawn, as this would imply quantitative knowledge of the total amount of copper to be discovered and mined in the United States. Second, the division between economic and subeconomic deposits is not shown as a single line because it changes with economic conditions. This division is shown graphically by a curve representing an estimate of the trend in cost/price ratios for the last 25 years. This curve is based on published U.S. reserves for 1950, 1960, and 1964; on the intensity of mineral exploration in late 1960 's; on the tonnage, grade and location of targets of interest during that period; and, finally, on the previously mentioned estimate that in 1975 a third of the U.S. copper mines were operating at a loss. The vertical axis of the plot has no scale, but a careful economic analysis of the copper industry could produce a scale based on copper prices and mining costs.

On the right side of figure 4, rectangles represent undiscovered resources. Their dimensions are based on estimates by Cox and others (1973) of about 100 million
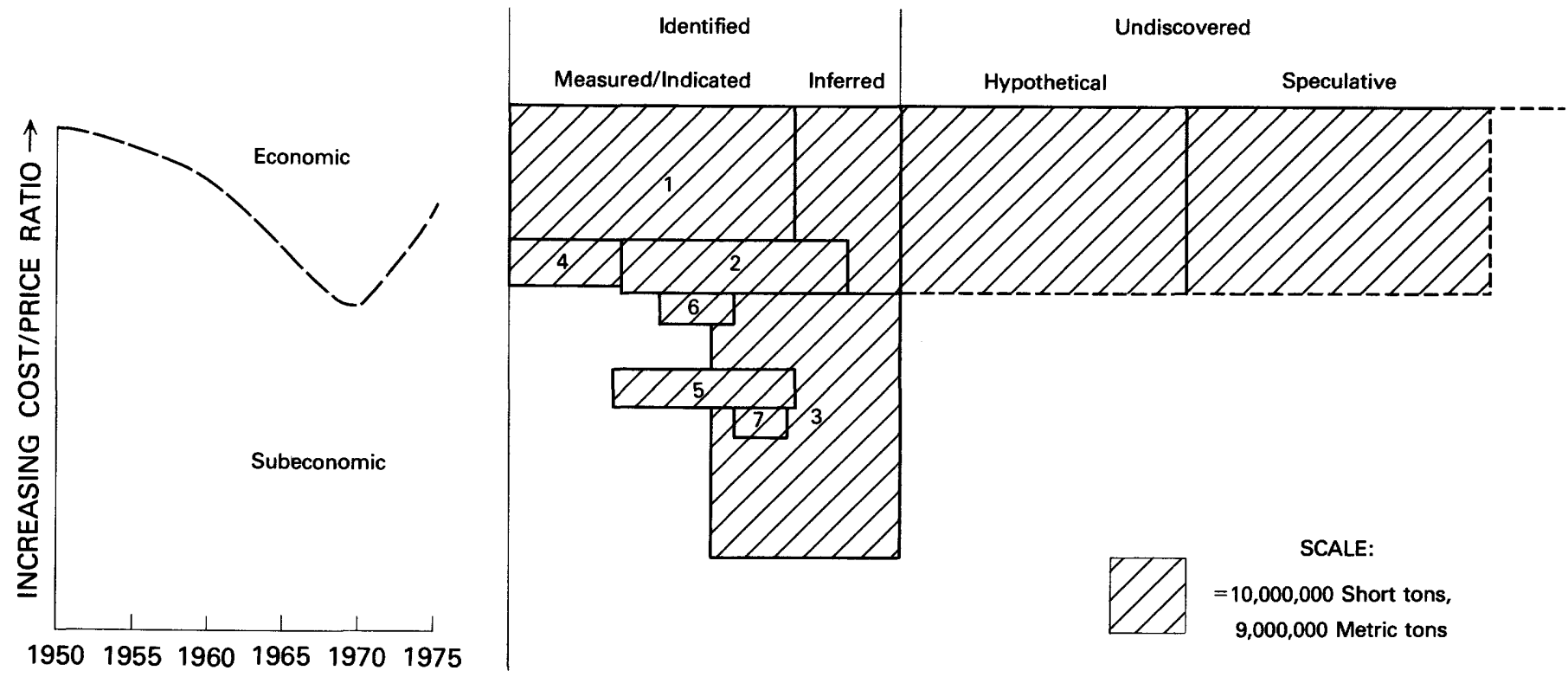

FIGURE 4.-Classification of U.S. copper resources and reserves. See text for explanation. 
tons in each of the two categories, hypothetical and speculative. Because of the large amount of copper known to exist in identified deposits, no further analysis of undiscovered resources has been made by the U.S. Geological Survey. Undiscovered resources are large; what must be stressed is that a large amount of effort is required to find the undiscovered deposits.

\section{PRODUCTION DATA}

For each mine-mill unit in the United States, records of annual production capacity, in terms of copper metal, as well as records of copper production of past years, have been collected. Total capacity of the 38 producing deposits is 2 million tons of recoverable copper annually. On the basis of these data, future annual production capacity has been estimated following methods described by Zwartendyk (1974) and by Martin and others (1976).

Annual production capacities are compared with total contained copper in ore on a logarithmic plot (fig. 5). Capacities range from less than 1,000 tons to 300,000 tons of copper per year and have a geometric mean of
33,000 tons per year. Logarithms of production capacities of metal mined per year show a high correlation with the logarithm of total contained copper per deposit.

Two regression equations are given as follows. One predicts annual production capacity, $C$, given total contained metal in ore reserves and past production, $M$. A second predicts $M$ given $C$ :

$$
\begin{aligned}
\log C & =0.652 \log M+0.572 \\
\log M & =1.310 \log C+0.134
\end{aligned}
$$

The correlation coefficient $R$ for these equations is 0.925 . Other regression equations relating annual capacity to total ore and to total ore and grade were tested and gave no significant improvement in the correlation coefficient.

Lines of planned mine life can be drawn through the data shown in figure 5; all deposits falling on one such line have the same ratio of production capacity to contained metal. The geometric mean of the data falls on the 30-year mine-life line. Note that the slope of the regression line is less than one, indicating that large deposits tend to have a lower ratio of production to

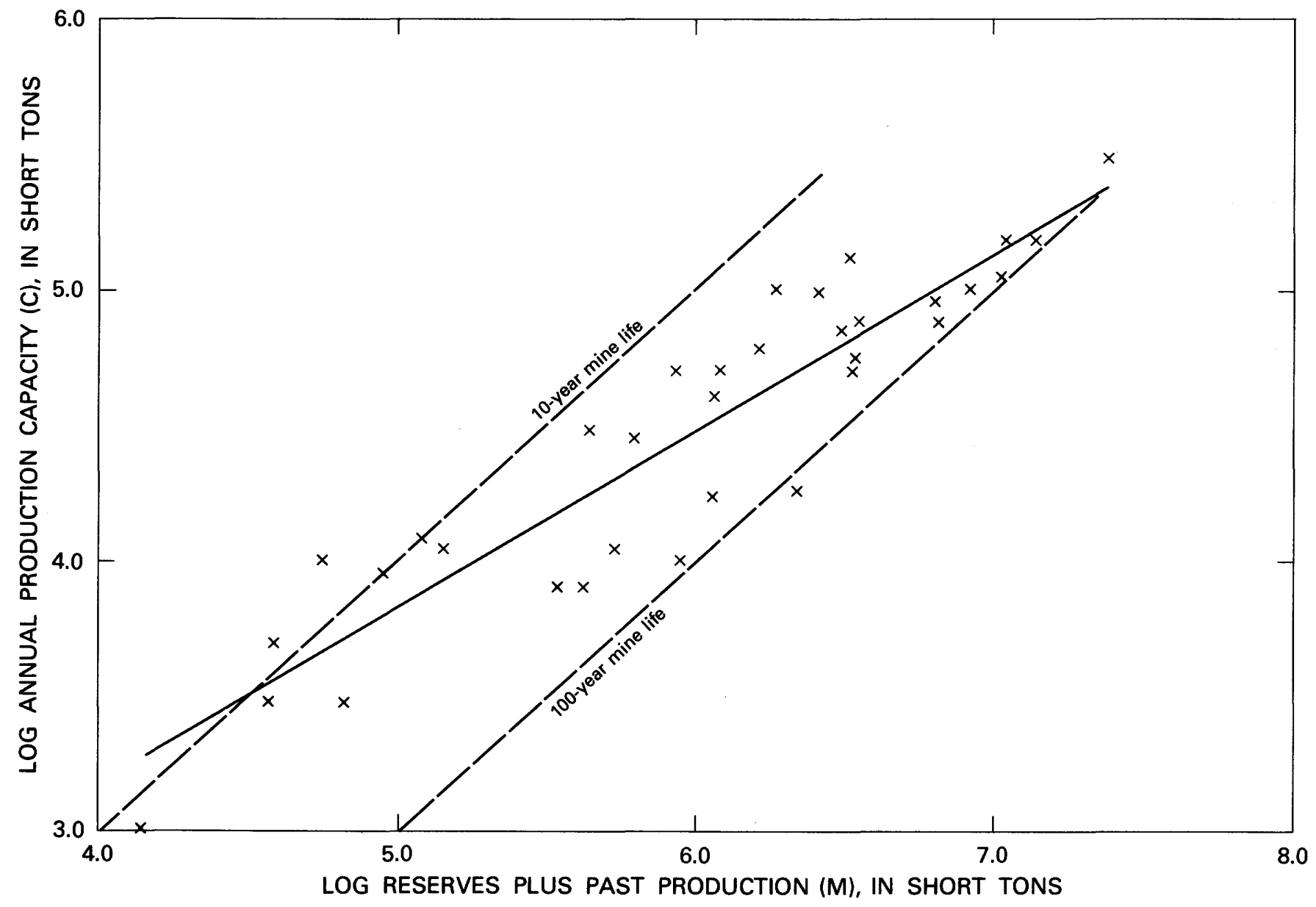

FigURE 5.-Log annual production capacity $(C)$ in relation to log total copper in ore (reserves plus past production $(M)$ for 34 deposits $(+)$. The solid line is the regression line. Dashed lines show ratios of annual capacity to contained metal or years of production per deposit. 
contained metal than do medium to small deposits. For example, the plot shows that 2 million tons of copper in 10 deposits (each having 200,000 tons contained copper) would be expected to yield slightly more metal per year than would one deposit containing 5 million tons. The above relationships describe the past behavior of U.S. mining firms in selecting the scale of operations for new mine developments. If this behavior is the same as that of mining firms in other countries, the relationships may be an important consideration in relating supply to reserves. Where most of a nation's reserves are contained in a few very large deposits, the reserve estimate could be as large as 100 times the annual production capacity. Where reserves are generally contained in many small deposits, reserves could be as small as $\mathbf{1 0}$ times the annual production capacity. Conversely, if past planning behavior continues into the future, we can say that the discovery of several medium-size deposits would yield a higher annual production than the equivalent tonnage in one large deposit.

The prediction of copper-production potential has serious limitations. We assume, for example, that the behavior of mining firms in selecting production rates will remain unchanged when, in fact, this behavior depends on such economic variables as inflation rate and cost of capital investment, as well as on new environmental regulations and improvements in extraction technology.

Another limitation is the high variability of the data, masked by the logarithmic scale used in figure 5. Note, for example, that for a 1-million-ton deposit, capacities range from 15,000 to 60,000 tons per year. Although precise statements cannot be made about the confidence limits in the real data because logarithms are used, the predicted value of capacity is probably within a factor of four of the real value.

Table 5 shows the results of applying the regression equation of figure 5 on a deposit-by-deposit basis to some of the resource categories of table 4. Estimates are not made for categories 3,5 , and 7 because it is not realistic to apply the regression equation to resources that cannot be exploited in the near future or to Alaska, where mining conditions are so different from those of the lower 48 States. The totals in table 5 are the result of solving the regression equation for each deposit. Application of the equation to the sum of the copper resources in any category gives a much smaller aggregate annual production potential because, by this method, the contribution of medium and small deposits is underestimated.

\section{ANTICIPATED COPPER PRODUCTION}

Future production of primary copper depends on the aggregate mine and mill, smelter, and refinery capacities and on the reserves of the commodity. If plants are operating near capacity, supply is slow to respond to
TABLE 5.-Potential annual production, in 1,000 toms per year, from U.S. copper deposits as of 1978.

\begin{tabular}{lcc}
\hline Categories & $\begin{array}{r}\text { Short or metric } \\
\text { tons per year }\end{array}$ \\
\hline 1 Operating mines ${ }^{1}$ - & 2,000 \\
2 Good deposits & 500 \\
4 Closed mines & 300 \\
6 Mines having environmental problems & 150 \\
\hline 1
\end{tabular}

increases in demand because existing mines and plants require significant time to expand and because grassroots development of drilled-out deposits requires 4-8 years from investment decision to production (Burgin, 1976). Future supply may be increased by new mineral technology that may make possible the conversion of subeconomic resources into reserves and by mineral exploration that converts undiscovered resources into reserves. Because the rate of technologic advance and mineral discovery is difficult to predict, no great confidence can be placed in estimates of total future supply.

Considerable confidence can be placed, however, in a minimum estimate of future production. This estimate is made by first assuming that no new deposits will be developed, that no extreme fluctuations in demand and price will take place, and that no changes in productive capacity will be made other than the planned changes already announced by mining firms. For each copper mine in the United States, a depletion date was calculated assuming production at full capacity. For any year, the sum of the individual annual production capacities for deposits not yet depleted provides an estimate of minimum U.S. production capacity. For example, a deposit having 100 million tons of reserves in 1978 at a grade of 1 percent copper will contain 1 million tons of copper. If production capacity is 40,000 tons of metal per year and if 80 percent of the copper is recovered from the ore, then the life of the deposit operating at capacity is 20 years, and its depletion date is 1998. The capacity of this mine is thus part of aggregate U.S. production for all years up to and including 1998.

Figure 6 shows a curve of minimum production for 1976-2030, based on 1978 data. The curve rises between 1976 and 1979 because of planned increases in capacity and announced development of new deposits, then falls steadily as existing small- and medium-tonnage deposits are depleted. Some of the largest deposits in the United States can be expected to supply copper until the year 2030 . The area under this curve is equivalent to the United States reserves and resources in categories 1 and 4. Zwartendyk (1974) has emphasized that this type of predictive calculation is more useful than that which simply compares the national reserve to anticipated cumulative consumption.

A family of curves may be drawn, each having a similar slope and enclosing increasingly larger areas. These areas represent tons of copper available under different 


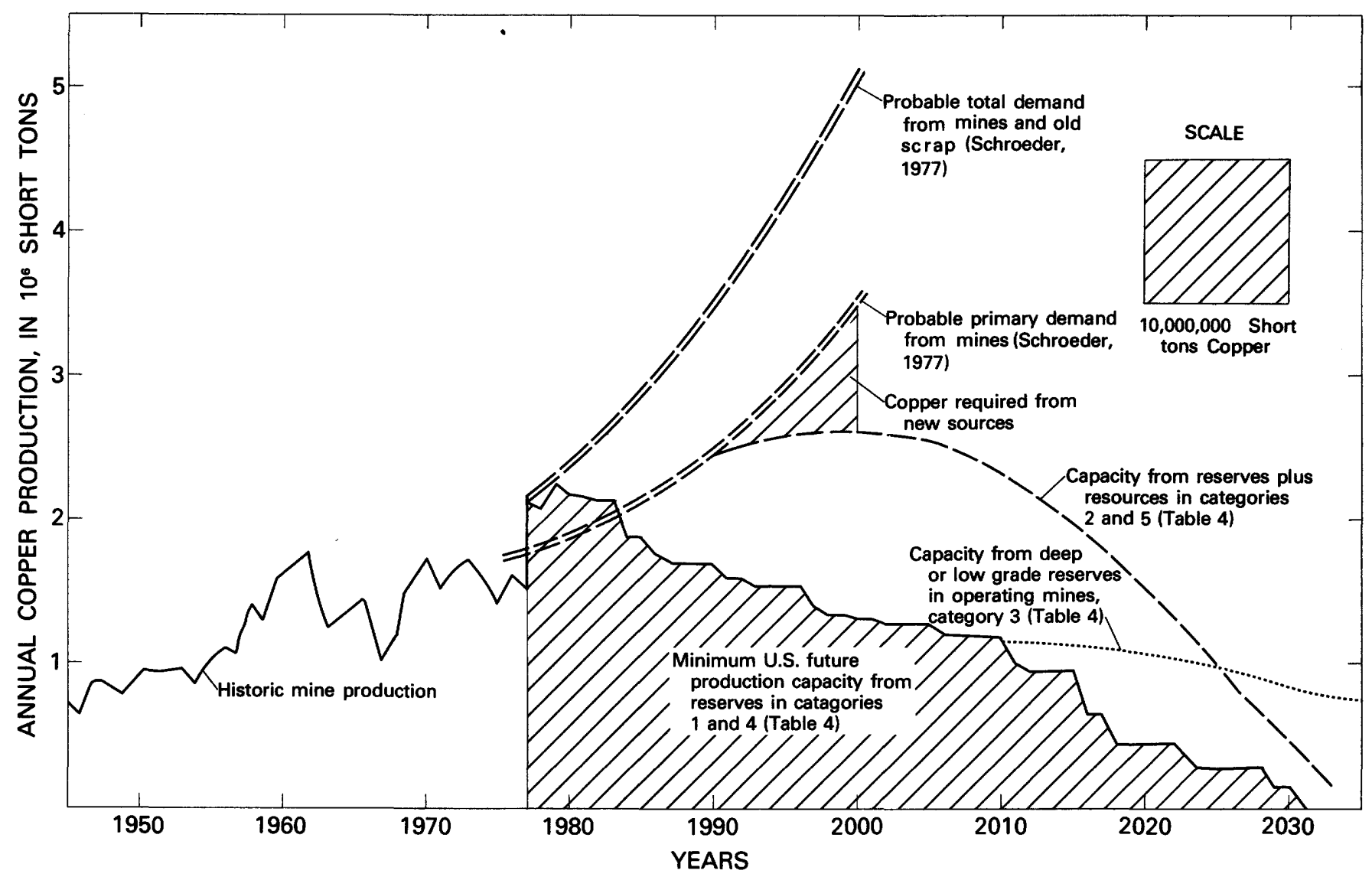

FIGURE 6.-Comparison of copper demand with U.S. production capacity projections, 1976-2030. (Demand projection from Schroeder, 1977.)

assumptions about the rate at which they will be converted into reserves. One of these curves, enclosing an area of $\mathbf{4 7}$ million tons, is shown in figure $\mathbf{6}$. This curve was made by assuming that the previously mentioned identified deposits, similar to those being mined (category 2), and those in deeply buried deposits (category 5) will be developed between 1985 and 1994. Other curves enclosing various categories of subeconomic deposits, as well as hypothetical and speculative resources, could be drawn, each with increasing uncertainty. Deposits of category 3, identified subeconomic resources in operating properties, will probably have no significant effect on production until the reserves in those deposits are nearly depleted. Thus, the tonnage of copper in this category will tend to raise the curve of minimum production capacity at its lower end and extend the curve considerably into the future.

\section{REQUIREMENTS FOR NEW SOURCES}

Two demand projections for copper, also shown on figure 6, have been taken from Schroeder (1977). The total demand projection is the amount of copper needed regardless of source. Because the amount of copper that can be recovered from old scrap is limited by cost and energy availability, a large part of total demand must be met by mined copper, either domestic or imported. This part is called primary demand. The most likely primary-demand projection based on a 2.9 percent per year growth rate indicates that demand is expected to be greater than mine capacity from reserves in category 1 by about 1983 and to be greater than total possible capacity from deposits in categories 2 and 5 by 1994. From 1994 on, the graph shows a widening gap between the primary-demand projection and the annual production-capacity curve. This gap represents the requirements of copper from new sources.

The magnitude of requirements for new sources cannot be precisely determined because some past and current discoveries of mining firms are kept confidential. Discussion with mining-company geologists indicates that the number and size of deposits in this discovered but unpublicized category is small in relation to the gap shown in figure 5. A greater uncertainty in the magnitude of the requirements from new sources is the slope of the demand projection. Although it is beyond the scope of this study to examine the assumptions behind such projections it is important to note that projections vary widely. Figure 6 , used as an interpretive tool, may be combined with any appropriate demand projection. The projected 3 percent growth in primary demand shown in figure 6 is based on Schroeder 
(1977). If a different projection is used, such as the 1.9 percent growth rate forecast by Malenbaum, ${ }^{2}$ requirements from new sources are considerably smaller.

Requirements from new sources can be met in one or a combination of four ways: by increasing imports, by increasing plant capacities at operating properties, by technological improvements converting subeconomic resources to reserves, and by discovery and development of new deposits.

Imports of copper are likely to increase in the next 20 years as costs of domestic production rise above average costs of production in the rest of the world. In the developing countries, copper mining and exploration have been less intensive than in the United States, and major low-cost reserves are still being discovered and developed. Chile's identified copper reserves of 107 million tons (Sutulov, 1977), for example, have doubled since the 1960 's and now are greater than U.S. reserves. These reserves are in ore that has an average grade of 1.0-1.2 percent copper compared with $0.7-0.8$ percent for U.S. resources. The relationship between grade of reserves in the United States, Chile, Peru, Zambia, and Zaire is shown in figure 7. Not only the decreasing grade of domestic production but also the increasing depth of deposits and the increasing stringency of environmental controls are driving up U.S. mining costs relative to those in the rest of the world. What effect increased imports will have on prices and assured copper supply for U.S. industry is difficult to predict. Although a cartel-like organization has been formed by Chile, Peru, Zaire, Zambia, and other copper-producing nations, its success in controlling prices is believed to be increasingly unlikely in view of the large number of countries now known to have important copper resources (Council on International Economic Policy, 1974). Radetzki (1977) has shown, however, that six developing countries having large low-cost copper reserves (Chile, Papua-New Guinea, Peru, Philippines, Zaire, and Zambia) could gain a 51-percent share of the world market by the year 2000 . Investment in expansion of production of high-cost reserves in the United States and Canada, as well as in new production from countries that have no present copper industry (Argentina and Panama), would be curtailed in the face of increased production from the six countries, according to Radetzki.

Increases in plant capacities at presently operating properties can temporarily raise the minimum production-capacity curve. Production increases, however, increase the rate of mine depletion and make the slope of the curve steeper. The supply problem is only postponed by a few years.

As discussed earlier, technological improvements, such as those in the field of in-place leaching of ores, may contribute new production to fill the widening gap.

\footnotetext{
${ }^{2}$ Malenbaum, Wilfred, 1977, World demand for raw materials 1985-2000: National Science Foundation unpublished report, p. 116.
}

Energy-intensive methods for winning metals from low-grade deposits, however, will make only small contributions to increasing production.

Discovery and development of new deposits can provide sufficient production to fill the widening gap. If we assume a 3 percent growth in demand, by 2000 , the gap between production capacity from known deposits and the most probable primary demand will approach 1 million tons of annual production. This gap could be closed by the discovery and development of 3 giant deposits or about 30 average-size deposits (1 million tons of contained copper each). Because of the 4-8 year lead time between discovery and first production, this $\mathbf{3 0}$ million tons of new copper reserves must be identified by 1985 or 1990 , calling for a rate of discovery and development of about 2 million tons of copper in ore per year.

To put this requirement in proper perspective, we may wish to know at what rate copper ore has been discovered in the past. Reliable data on discovery dates are difficult to obtain, but as a close approximation, dates of first production can be used. In general, the first production year follows, by 4-8 years, the discovery or first recognition of the economic value of a deposit. Figure $8 A$ shows the total tonnage of copper in reserves brought into production in 10-year periods. The vertical bars are totals of past mine production and reserves as they are now known, credited back to the year of first production. Black bars represent the number of deposits developed in the same 10-year period.

The bar graph shows a very large peak at the beginning of the century that represents the development of the Bingham deposit in Utah in 1904, Morenci in Arizona in 1907, and the Robinson District in Nevada in 1908. From 1910 to 1920 , the Miami, Inspiration, Ray, and Ajo deposits in Arizona and the Chino deposit in New Mexico were brought into production. A lull during the depression years was followed by increased development in the World War II era, marked by the opening of San Manuel in Arizona in 1956. The bars for the 1980-1990 period are projected on the optimistic assumption that all the known deposits of categories 2 and 5 will be developed within that period.

Since 1960, the number of deposits developed per 10 -year period has increased greatly without a commensurate increase in tonnage of copper. This trend may result partly from inadequate knowledge of the true tonnage of recently developed deposits. In recent years, however, firms increasingly have tended to drill out reserves fully before mining is begun. The trend more probably reflects decreasing grade (and copper content) of deposits and increasing numbers of small deposits containing small amounts of copper. For example, the average grade in the 38 producing mines in the United States is 0.74 percent copper compared with an average grade of 0.53 percent in the undeveloped deposits of categories 2 and 5 . 


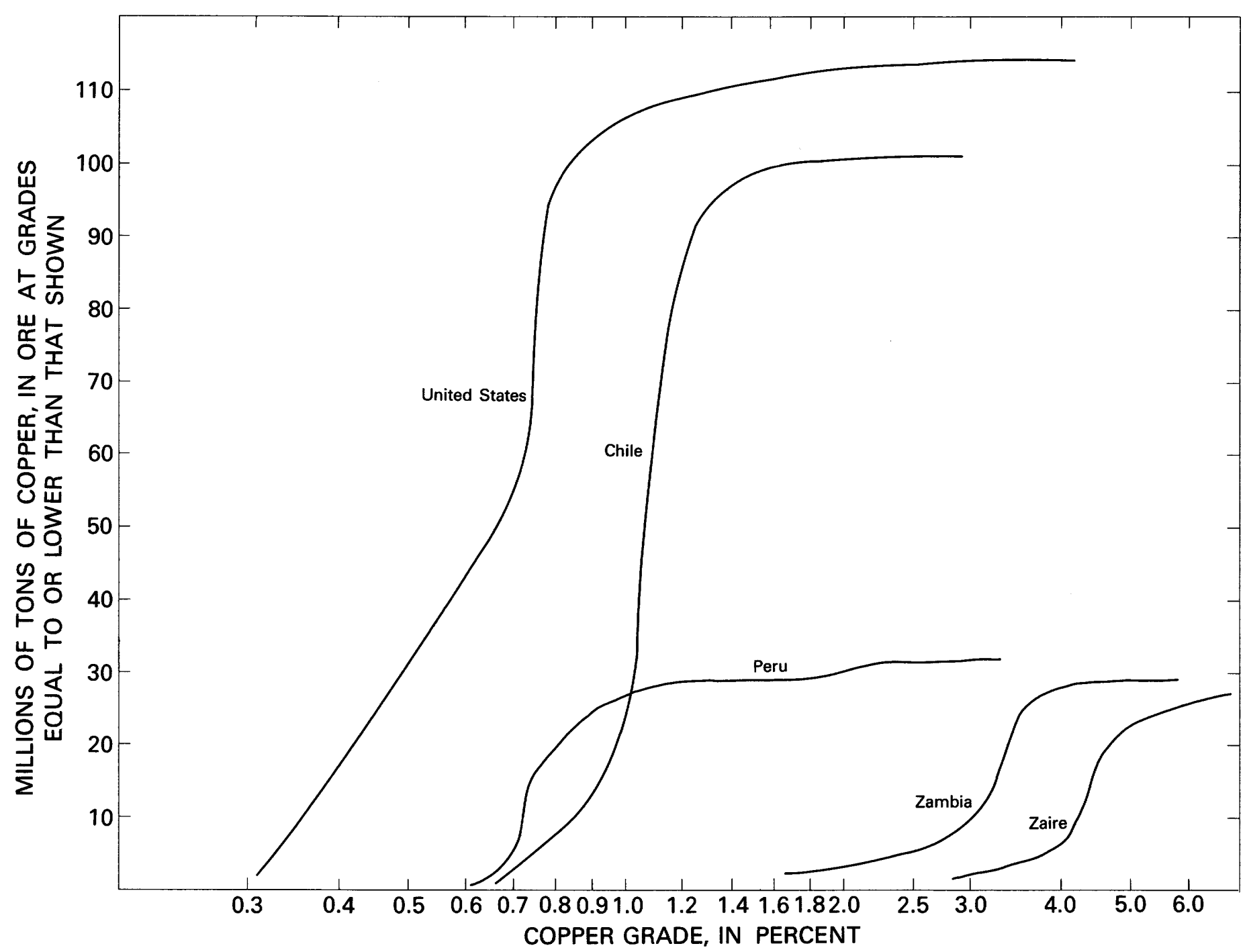

FIGURE 7.-Cumulative reserves and resources at various grades in the United States, Chile Peru, Zambia, and Zaire, as of 1977. U.S. reserves and resources include categories $1,2,4,5$, and 6 (table 4). For the other four countries, all published reserves estimates were included.

Figure $8 B$ shows the historic development of copper in ore and is derived by plotting cumulatively the same data used to make the bar graph in figure $8 A$. This cumulative curve is compared with cumulative mine production and consumption. For any year, the U.S. reserve in producing mines can be found by subtracting the amount of copper shown by the cumulative mineproduction curve from the cumulative copper in developed ore. The reserve values thus calculated are plotted on figure 1 and compared with historic reserve estimates. The early estimates are low mainly because the magnitude of reserves in some of the largest U.S. deposits have only become known in recent years.

The curve of cumulative copper in developed ore rises sharply in the 1900-1920 period because technological breakthroughs in material handling and mineral processing affected economic evaluation of copper deposits that had been discovered many years before.
The slope of the curve between 1950 and 1980 is equal to slightly more than a million tons of contained copper per year and represents the development of deposits whose discoveries required greater exploration effort.

The copper deposits now being mined were mainly recognized in surface outcrop. Many are surrounded by a halo of smaller base- and precious-metal deposits, which drew the attention of prospectors in the late 1800 's. Deposits to be found in the future will be those deeply covered by postmineral sedimentary and volcanic rock or that have no halo of other deposits. Thus, future discoveries will be considerably more difficult to make than were the discoveries of the deposits making up our present reserves. Future discoveries must also meet increasingly severe production-cost criteria in order to obtain financing for development in competition with low-cost foreign deposits. 


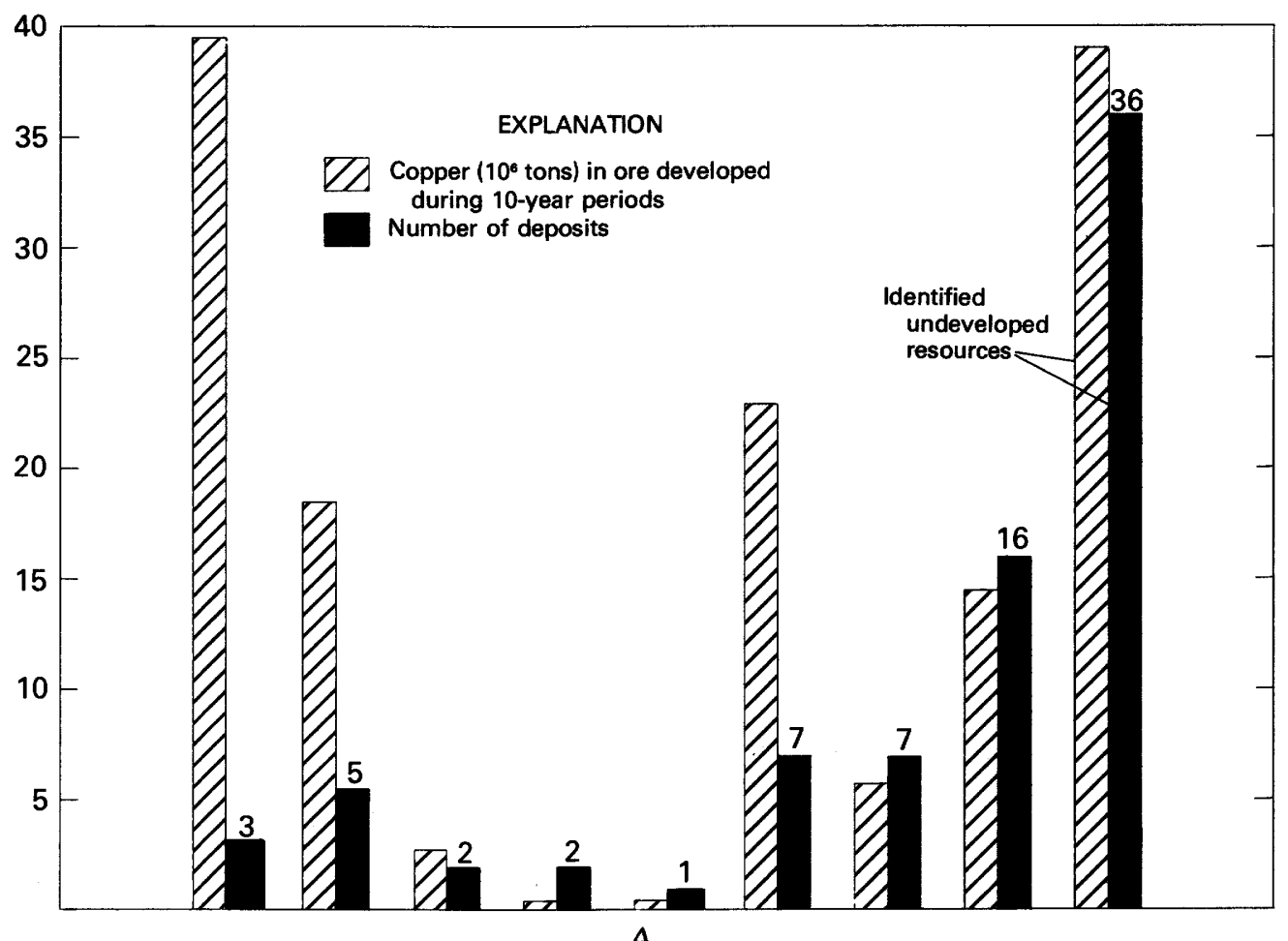

A

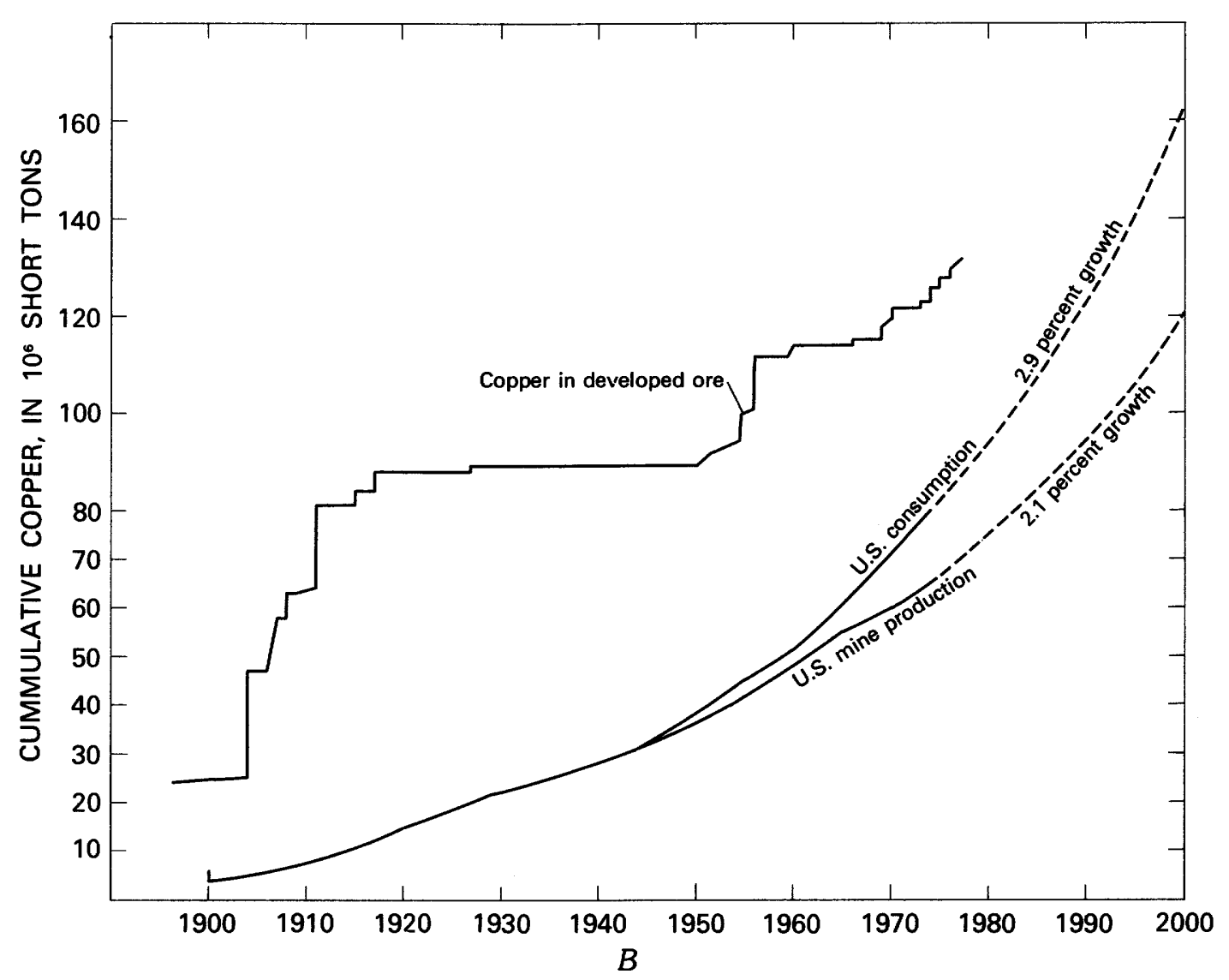




\section{CONCLUSIONS}

Some of the more notable conclusions that can be drawn from this study are as follows:

1. U.S. reserve estimates in the past have been low mainly because of incomplete knowledge of the magnitude of the very large porphyry deposits. Present estimates are considerably more reliable, mainly because mining firms tend to drill out deposits fully before mining and because many of these companies are willing to make reserve estimates public. The effect of economic fluctuations on reserve estimates can be minimized if nearterm anticipated economic conditions rather than present conditions are used to define reserves.

2. The wide variation in tonnage, grade, and contained metal in copper deposits depends largely on the geologic type of deposit. Of the four common deposit types, porphyry deposits are the most abundant, have the highest metal content, and largest aggregate production potential.

3. Resource data should be presented in the most disaggregated form possible because of the wide variety of conditions required to transform resources into reserves. Of the various resource categories discussed in this report, the largest tonnage of copper is contained in the deep parts of a small number of deposits known to be the largest in the country. These resources probably cannot make contributions to our supply until well after the year 2000, when present mining operations have nearly depleted the reserves and a changeover to a new mine plan can be made.

4. A high correlation exists between logarithms of annual production capacity and tonnage of contained copper in past production and reserves. A regression equation can be used to calculate the probable production capacity of a group of undeveloped deposits, but the large scatter of the antilog data makes such estimates accurate only within a factor of four. Analysis of production data shows that reserve requirements are smallest if annual production comes from medium- to smalltonnage deposits or, conversely, that large deposits yield a disproportionately small annual production relative to their large metal content.

5. A minimum future production capacity can be calculated by totaling, for any year, the production cap- acities of all deposits not yet depleted by that year. A curve can be drawn through these points showing declining production as smaller deposits are depleted. Such a curve, when compared with projected primary consumption is useful in estimating the requirements of copper from such new sources as imports or deposits not yet discovered. A comparison with one demand projection (Schroeder, 1977) suggests that if the new sources are to be from copper in domestic deposits, this copper must be found and developed at the rate of 2 million tons per year. Discovery and development of copper in the United States since 1950 has been at a rate slightly greater than 1 million tons per year.

\section{REFERENCES CITED}

Bennett, H. J., Moore, Lyman, Welborn, L. E., and Toland, J. E., 1973, An economic appraisal of the supply of copper from primary domestic sources: U.S. Bureau of Mines Information Circular 28598, 156 p.

Bennett, H. J., Thompson, J. G., Quiring, H. J., and Toland, J. E., 1970 , Financial evaluation of mineral deposits using sensitivity and probabilistic analysis methods: U.S. Bureau of Mines Information Circular 8495, 82 p.

Bonnichsen, Bill, 1974, Copper and nickel resources in the Duluth Complex, northeastern Minnesota: Minnesota Geological Survey Information Circular 10, $24 \mathrm{p}$.

Bottge, R. G., 1974, Comparative porphyry copper mining and processing costs-Alaska and Arizona: U.S. Bureau of Mines Information Circular 8656, 55 p.

Bowen, R. W., and Botbol, J. M., 1975, The geologic retrieval and synopsis program (GRASP): U.S. Geological Survey Professional Paper 966, $87 \mathrm{p}$.

Brobst, D. A., 1979, Fundamental concepts for the analysis of resource availability, in Smith, V. K., ed., Scarcity and growth reconsidered: Baltimore, Md., published for Resources for the Future by the Johns Hopkins University Press, p. 106-142.

Burgin, L. B., 1976, Time required in developing selected Arizona copper mines: U.S. Bureau of Mines Information Circular 8702, $144 \mathrm{p}$.

Committee on Mineral Resources and the Environment, National Research Council, 1975, Resources of copper, in Mineral resources and the environment: Washington, D.C., National Academy of Sciences, p. 127-187.

Cook, Earl, 1976, Limits to exploitation of nonrenewable resources: Science, v. 191, no. 4228, p. 677-682.

Council on International Economic Policy, 1974, Special report critical imported material: Washington, D.C., U.S. Government Printing Office, $110 \mathrm{p}$.

Cox, D. P., Schmidt, R. G., Vine, J. D., Kirkemo, Harold, Tourtelot, E. B., and Fleischer, Michael, 1973, Copper, in Brobst, D. A., and Pratt, W. P., eds., United States mineral resources: U.S. Geological Survey Professional Paper 820, p. 163-189.

Figure 8.-Plots showing rate of development of copper in ore in the United States, 1900 to 2000 . A, Tonnage of copper in reserves and number of deposits brought into production and potentially producible, by 10-year periods, 1900-1980. Tonnage of copper is shown in crosshatched bars. Number of deposits developed is shown by black bars. Bars shown for the period 1980-1990 represent copper in identified deposits potentially producible (categories 2 and 5 , table 4). $B$, Cumulative copper in developed ore reserves, cumulative consumption, and cumulative mine production. The copper-in-ore curve is projected to 1990 and 2000 . The consumption curve is projected at a 3-percent growth rate (Schroeder, 1977), and the mine production curve is projected at the rate of past increase, 2 percent. For any year, the difference between cumulative copper in developed ore and cumulative mine production equals total U.S. ore reserves for that year, as calculated from modern reserve data. 
Everett, F. D., and Bennett, A. J., 1967, Evaluation of domestic reserves and potential sources of ores containing copper, lead, zinc, and associated metals: U.S. Bureau of Mines Information Circular 8325, $78 \mathrm{p}$.

Greenspoon, G. N., and Morning, J. L., 1976, Froth folation in 1975-advance summary: U.S. Bureau of Mines Mineral Industry Surveys, 23 p.

Joralmon, I. B., 1973, Copper: Berkeley, Calif., Howell-North Books, $407 \mathrm{p}$.

McKelvey, V. E., 1972, Mineral resource estimates and public policy: American Scientist, v. 60, no. 1, p. 32-40.

McMahon, A. D., 1965, Copper, a materials survey: U.S. Bureau of Mines Information Circular 8225, $340 \mathrm{p}$.

Maloney, R. P., and Bottge, R. G., 1973, Estimated costs to produce copper at Kennecott, Alaska: U.S. Bureau of Mines Information Circular 8602, 35 p.

Martin, H. L., Cranstone, D. A., and Zwartendyk, Jan, 1976, Metal mining in Canada to the year 2000: Resources Policy, v. 2, no. 1, p. 11-24.

Metals Week, 1973-74, Metals sourcebook: New York, McGraw Hill, (bi-weekly publication).

Mining Journal, 1972-75, Mining annual review: London, Mining Journal Ltd.

Parsons, A. B., 1933, The porphyry coppers: New York, American Institute of Mining and Metallurgical Engineers, $581 \mathrm{p}$.

Phillips, C. H., 1975, Discussion: A resource analysis based on porphyry copper deposits and the cumulative copper metal curve using Monte Carlo simulation: Economic Geology, v. 70, no. 8, p. 1484.

Radetzki, Marian, 1977, Mineral commodity stabilization: The producers view: Resources policy, v. 3, no. 2, p. 118-126.

Ridge, J. D., ed., 1968, Ore deposits of the United States, 1933-1967 (Graton-Sales Volume): New York, American Institute of Mining Metallurgical and Petroleum Engineers, 2 v.: 1880 p.
Rosenkranz, R. D., 1976, Energy consumption in domestic primary copper production: U.S. Bureau of Mines Information Circular $8698,22 \mathrm{p}$.

Schanz, J. L., 1975, Resource terminology: an examination of concepts and terms and recommendations for improvement: Electric Power Research Institute (Palo Alto, Calif.), EPRI report 336, $116 \mathrm{p}$.

Schroeder, H. J., 1977, Copper: U.S. Bureau of Mines Mineral Commodity Profiles, no. 3, 19 p.

Singer, D. A., 1975, Mineral resource models and the Alaskan Mineral Resource Assessment Program, in Vogely, W. A., ed., Mineral materials modelling: Washington, D.C., Resources for the Future, p. $370-382$.

Singer, D. A., Cox, D. P., and Drew, L. J., 1975, Grade and tonnage relationships among copper deposits: U.S. Geol. Survey Professional Paper 907-A, p. A1-A11.

Sutulov, Alexander, 1977, Chilean copper resources said to be world's largest: American Metals Market, v. 85, no. 150, p. 18.

Titley, S. R., and Hicks, C. L., eds., 1966, Geology of the porphyry copper deposits southwestern North America: Tucson, Ariz., University of Arizona Press, 287 p.

Tourtelot, E. B., and Vine, J. D., 1976, Copper deposits in sedimentary and volcanogenic rocks: U.S. Geological Survey Professional Paper 907-C. 34 p.

U.S. Bureau of Mines, 1977, Copper, in Commodity data summaries, 1977: Washington, D.C., p. 46-47.

U.S. Bureau of Mines and U.S. Geological Survey, 1980, Principles of a resource/reserve classification for minerals: U.S. Geological Survey Circular 831, 5 p.

Zwartendyk, J., 1974, The life index of mineral reserves-a statistical mirage: Canadian Mining and Metallurgical Bulletin, v. 67, no. 750, p. 67-70. 


\section{Geology and Resources of Copper Deposits}

GEOLOGICAL S UR VEY PROFESSIONAL PAPER 907

This volume was published as separate chapters $A-F$

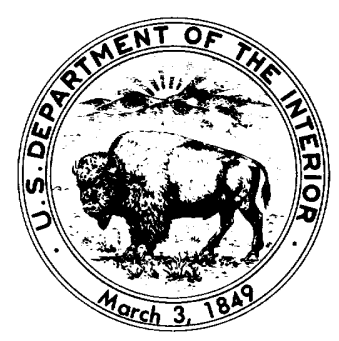


UNITED STATES DEPARTMENT OF THE INTERIOR

JAMES G. WATT, Secretary

GEOLOGICAL SURVEY

Dallas L. Peck, Director 


\section{CONTENTS}

[Letters designate the chapters]

(A) Geology and Resources of Copper Deposits-Grade and Tonnage Relationships Among Copper Deposits, by D. A. Singer, Dennis P. Cox, and Lawrence J. Drew

(B) Geology and Resources of Copper Deposits-Geochemical Exploration Techniques Applicable in the Search for Copper Deposits, by Maurice A. Chaffee

(C) Geology and Resources of Copper Deposits - Copper Deposits in Sedimentary and Volcanogenic Rocks, by Elizabeth B. Tourtelot and James D. Vine

(D) Geology and Resources of Copper Deposits-Fluid-Inclusion Petrology-Data from Porphyry Copper Deposits and Applications to Exploration, by J. Thomas Nash

(E) Geology and Resources of Copper Deposits - The Potential for Porphyry Copper-Molybdenum Deposits in the Eastern United States, by Robert Gordon Schmidt

(F) Geology and Resources of Copper Deposits-The Nature and Use of Copper Reserve and Resource Data, by Dennis F. Cox, Nancy A. Wright, and George J. Coakley 





\section{.}

